\title{
Effects of chronic bottom trawling on soft-seafloor macrofauna in the Kattegat
}

Sköld, Mattias; Göransson, Peter; Jonsson, Patrik; Bastardie, Francois; Blomqvist, Mats; Agrenius, Stefan; Hiddink, Jan Geert; Nilsson, Hans C.; Bartolino, Valerio

Published in:

Marine Ecology - Progress Series

Link to article, DOI:

$10.3354 /$ meps 12434

Publication date:

2018

Document Version

Peer reviewed version

Link back to DTU Orbit

Citation (APA):

Sköld, M., Göransson, P., Jonsson, P., Bastardie, F., Blomqvist, M., Agrenius, S., Hiddink, J. G., Nilsson, H. C., \& Bartolino, V. (2018). Effects of chronic bottom trawling on soft-seafloor macrofauna in the Kattegat. Marine Ecology - Progress Series, 586, 41-55. https://doi.org/10.3354/meps12434

\section{General rights}

Copyright and moral rights for the publications made accessible in the public portal are retained by the authors and/or other copyright owners and it is a condition of accessing publications that users recognise and abide by the legal requirements associated with these rights.

- Users may download and print one copy of any publication from the public portal for the purpose of private study or research.

- You may not further distribute the material or use it for any profit-making activity or commercial gain

- You may freely distribute the URL identifying the publication in the public portal 


\section{Effects of chronic bottom trawling on soft seafloor macrofauna in the}

\section{Kattegat}

4 Running page head: Effects of trawling on macrofauna in the Kattegat

5

6 Authors: Mattias Sköld ${ }^{1 *}$, Peter Göransson ${ }^{2}$, Patrik Jonsson ${ }^{1}$, Francois Bastardie ${ }^{3}$, Mats

7 Blomqvist $^{4}$, Stefan Agrenius ${ }^{5}$, Jan Geert Hiddink ${ }^{6}$, Hans C. Nilsson ${ }^{1}$, Valerio Bartolino ${ }^{1}$

$9{ }^{1}$ Department of Aquatic Resources, Institute of Marine Research, Swedish University of 10 Agricultural Sciences, SE453 30 Lysekil, Sweden

11 2PAG Environmental Research, SE252 70 Råå, Sweden

$12{ }^{3}$ National Institute of Aquatic Resources, DTU Aqua Technical University of Denmark, 2920

13 Charlottenlund, Denmark

$14{ }^{4}$ Hafok AB, SE179 61 Stenhamra, Sweden

$15{ }^{5}$ Department of Marine Sciences Kristineberg, University of Gothenburg, SE451 78 16 Fiskebäckskil, Sweden

$17{ }^{6}$ School of Ocean Sciences, Bangor University, Menai Bridge, Anglesey, LL59 5AB, United 18 Kingdom

$20 *$ corresponding author: mattias.skold@slu.se

22 Abstract: Chronic impact studies of bottom trawling aiming to reveal long term effects on

23 benthic organisms are often hampered by the lack of comparable untrawled conditions and the

24 difficulty to assess the spatial distribution of trawling intensity. We sampled soft sediment

25 macrofauna over a precise trawling gradient in the Kattegat using hourly vessel monitoring 
systems and logbooks. The gradient accounted for the establishment of a marine protected area where trawling intensity declined sharply. Our results show shifts in the macrofauna assemblage and non-linear responses with decrease in number of species and diversity from low to medium trawling intensities. The benthic community was dominated by burrowing brittle stars, and one of the species Amphiura chiajei increased in abundance from low to medium trawling intensities. We interpret the positive response to increasing trawling intensities as a consequence of reduction in predation by benthivorous flatfish and Nephrops norvegicus that are significant catches of the fishery. The response was supported by a corresponding trend towards lower abundance of the dominating brittle stars following enforcement of the MPA and presumably an increase in benthivor density and predation pressure within the MPA. We conclude that chronic bottom trawling reduces diversity, and may boost the abundances of species resistant to bottom trawling. The results emphasize the need to consider food web effects when assessing the impact of bottom trawling.

Key words: Physical disturbance, Amphiura filiformis, Echinoderm, Otter trawling, Fishing impact, Food web, Benthic habitats, Nephrops norvegicus, Anti-predator defenses 


\section{INTRODUCTION}

Bottom trawls are designed to catch fish and shellfish that live on and close to the seabed and are therefore by design in contact with the seabed. As a result, bottom trawling can lead to disturbance of benthic habitats, and changes in the abundance, biomass and diversity of communities and species (Collie et al. 2000; Kaiser et al. 2006). Sensitivity of benthic habitats tends to be lower in shallow high energy areas with high levels of natural disturbance, than in deeper areas where physical disturbance by waves caused by wind driven energy, i.e. storms may not reach the seabed (van Denderen et al. 2015). Sensitivity of the fauna also differs between species depending on their biological traits and the mechanism of disturbance. Direct mortality of organisms and longer-term modification of habitats by mobile demersal fishing gear are most severe in vulnerable areas such as deep-water coral reefs and sponge communities where fragile species that build three-dimensional structures make up a significant component of the habitats (Fosså et al. 2002, Greathead et al. 2007, Jørgenssen et al. 2016). Other components of the fauna, like sediment dwelling infauna may be less sensitive to the direct physical impact because they are partly protected by burying in the substrate (Tillin et al. 2006). For such species, indirect effects such as changes in particle dynamics of the sediment (Dounas et al, 2007, Tjensvoll et al. 2013), or changes in the balance between predators and prey (Hiddink et al. 2016) and their interactions, or whether the abundance of benthos is top-down or bottom-up controlled (van Denderen et al. 2013), may have larger impacts.

The effects of bottom trawling impact on seafloor species, communities and habitats have been widely studied, and although some general patterns are emerging, there remains a lot of unexplained variation in the findings of individual studies (discussed in e.g. Collie et al. 2000, 
Løkkeborg 2005, Kaiser et al. 2006). The variation in outcomes of studies may relate to variations in fishing pressures as well variations in the sensitivity of the system studied or other environmental factors that may interact with fishing. In a recent global analysis of depletion and recovery of benthic fauna based on gradient studies only 5 of 24 studies included unfished conditions in their gradient of trawling (Hiddink et al. 2017). Observational studies that sample over existing gradients in trawling intensity may thus suffer from a lack of appropriate reference conditions, i.e. comparable sites without or with low bottom trawling intensity

Fishing activities are patchy and concentrated on specific fishing grounds due to accumulated knowledge by the fishers on catchability of target species, and accessibility by the gears used (e.g, Bastardie et al, 2010, Eigaard et al. 2016a). Likewise, benthic communities are patchy due to the spatial heterogeneity of factors structuring the communities such as the sediment composition, depth, hydrodynamic regime and food availability (e.g. Rosenberg and Möller 1979; Gogina et al.2016). With the introduction of satellite monitoring of fishing vessels and developed techniques to analyse and reconstruct fishing activities it has been increasingly clear how certain areas and habitats periodically are fished intensively, while other areas are fished in low intensities or not at all (Eigaard et al. 2016b, ICES 2016). These large spatial and temporal differences occur both on the wide scale between and within sea areas and on much finer scales of about 100 meters. It is crucial to assess the spatial distribution of bottom trawling intensity at a fine resolution if the aim of impact studies is to cover long term impact and effects of direct disturbance of the seafloor. This is because relationships between trawling and responses might otherwise be confounded by misclassification of the pressure at the site where the impact is studied. A universal problem for observational studies of trawling gradients is that trawling intensity, for practical and data access reasons is aggregated within 


\section{Study area}

grid cells much larger than the sampled site, usually 1 X $1 \mathrm{~nm}$ or larger (e.g. Hiddink et al. 2006, Reiss et al. 2009, Eigaard et al. 2016b, ICES 2016, Pommer et al. 2016). This may lead to unreliable estimations of the trawling intensity because large areas are likely to overestimate the trawling intensity in lightly trawled sites and underestimate the trawling intensity in heavily trawled sites. To our knowledge, no bottom trawling gradient study of benthic fauna communities have assessed the trawling intensity on a fine scale directly on the sampled position using a Euclidian radial distance approach.

The aim of this study was to evaluate the effects of bottom trawling on benthic macrofaunal assemblages using fine resolution trawling distribution data and untrawled reference conditions. We hypothesize that benthic macrofauna will be influenced by trawling intensity and evaluate this by stratifying a sampling programme in relation to a known bottom trawling gradient in the Kattegat. The power to detect effects was maximized by precisely assessing the trawling pressure to the sites where the sampling was carried out. The stratification took into account the establishment of a marine protected area (MPA) where bottom trawling was stopped to ensure as far as possible the inclusion of comparable untrawled conditions. We also study the effect on the macrofauna following the enforcement of the MPA, and hypothesize that temporal changes in the assemblage within the MPA will deviate from changes outside the MPA where trawling continues.

\section{MATERIAL AND METHODS}

116 
117 Kattegat is a shallow (mean depth $27 \mathrm{~m}$ ) sea area between Sweden and Denmark and connects

118 to the Skagerrak in the north and to the Baltic Sea via narrow straits in the south. The

119 influence from the Baltic Sea by low saline surface waters creates a typical estuarine

120 circulation pattern and strongly stratified water masses separated by a halocline that persists

121 all year round at around $15 \mathrm{~m}$ depth but may extend down to $20 \mathrm{~m}$ (Granéli 1992). The

122 outflow from the Baltic, the so called Baltic current is mostly concentrated along the Swedish

123 coast where the halocline is deeper and stratification stronger than in the western parts. The

124 water beneath the halocline, originating from Skagerrak and the North Sea is more stable and

125 marine conditions prevail with salinity conditions usually above 32 PSU (Andersson and

126 Rydberg 1988). Depths and substrate vary with shallow areas with sandy sediments in the

127 west and deeper soft mud sediments in the east (Hallberg et al. 2010). Benthic fauna in the

128 soft mud habitats are today dominated by brittle stars of the Amphiura-community (Gogina et

129 al. 2016), but especially the south-eastern part was earlier dominated by amphipods of the

130 Haploops community (Petersen 1913).

132 Fishing by bottom trawling in the Kattegat has been ongoing since early 1900 and target

133 gadoid fish and flatfish in the south-eastern part of the Kattegat mainly using otter trawls

134 (Bartolino et al. 2012). Off cod spawning season, and today all year round, the fishery is

135 dominated by otter trawling targeting Norway lobster Nephrops norvegicus or Nephrops and

136 a mixture of fish, mainly plaice Pleuronectes platessa, sole Solea solea and cod Gadus

137 morhua (Hornborg et al. 2016). Denmark has the largest share (67\%) of the Total Allowable

138 Catch (TAC) of Nephrops, Sweden has the second largest share (31\%), while Germany has

139 the smallest share of demersal fish and Nephrops (ICES 2015).

140 
141 In 2009 a large $\left(653 \mathrm{~km}^{2}\right)$ marine protected area, (MPA), was closed for all fishing activities

142 in the southeast Kattegat to protect spawning grounds for cod G. morhua. The MPA was one

143 of the core spawning areas that was fished by otter trawls historically for about 100 years

144 targeting aggregated cod during spawning season and Nephrops and mixture of fish the rest of

145 the year (Vitale et al. 2008). Some illegal fishing activities was documented the first year after

146 establishment of the MPA but seem to have decreased following actions taken by the Swedish

147 and Danish enforcement agencies (Bergström et al. 2016).

\section{Assessment of trawling intensity}

Trawling intensity was estimated as precisely as possible for each sampling site in relation to

152 the spatial resolution of the trawl path of the vessels within a radius of $250 \mathrm{~m}$ around the

153 location benthic macrofauna were sampled. The method of using the Euclidian radial distance

154 to a sampling station and interpolated trawl tracks has been shown to be consistent and

155 accurate when compared to true distributions of trawl tracks for otter trawls (Lambert et al.

156 2012). The Swedish and Danish fleets equipped with vessel monitoring systems (VMS) were

157 analysed using the VMStools R package (Hintzen et al. 2012) and protocols developed and

158 described in Eigaard et al. (2016a). VMS covers hourly updated GPS positions for vessels of

$15915 \mathrm{~m}$ length and larger over the period $2006-2011$, and all vessels of $12 \mathrm{~m}$ length and larger

160 during 2012 - 2014. Based on logbook information of the total effort in the Kattegat, we

161 estimated that the fleet coverage of vessels with VMS increased over the period studied from

$16250-60 \%$ in $2006-2011$ to $>75 \%$ in $2012-2014$. The VMS data set was interpolated into

163 positional data with 12 minutes' temporal resolution (Hintzen et al, 2010). The spread

164 between the trawl doors was estimated for each logbook trip based on the gear used and the

165 vessel's engine power (Eigaard et al. 2016a). This estimate was combined with interpolated 
VMS data to reconstruct individual trawl paths. Trawling intensity was then calculated around

167 the sampled position for benthic fauna as the area swept by trawls within the $250 \mathrm{~m}$ radius at each station and summed over 32 months prior to the sampling date. The time scale of accumulating trawling over 32 months was chosen to achieve a wide gradient $\left(0-15 \mathrm{yr}^{-1}\right)$ of the bottom trawl history, accumulate the index to cover more than one benthos recruitment event at a sampling station, and as a reasonable match to recovery time of the long living and presumably more sensitive part of the macrofauna species. To ensure that the gradient was consistent and comparable over time, data on trawling intensity was standardised to vessels $\geq$

$17415 \mathrm{~m}$ in all the analyses.

\section{Benthic macrofauna sampling}

Sampling of benthic macrofauna was carried out in May - June in 2009, 2010, 2011 and 2014 using a modified Smith-McIntyre grab $\left(0.1 \mathrm{~m}^{2}\right)$ at 58 stations (Fig. 1). One sample was taken per station and sieved (1.0 mm mesh size) for macrofauna. Sediment properties mapped by Hallberg et al. (2010) was inspected by eye and fingers for each sample and for all stations verified as soft mud sediments sometimes mixed with fine sand -silt. Samples were stored in $4 \%$ borax buffered formaldehyde prior to sorting, counting and weighing. With few exceptions, e.g. species belonging to the genus Edwardsia and the amphipod family Aoridae, all taxa were identified to species level.

187 All statistical analyses on biomass were tested without large bodied species, i.e. the heart urchins Brissopsis lyrifera and Echinocardium cordatum, and the ocean quahog Arctica islandica that due to their individual weight in some samples may strongly influence the outcome of the results. The distance based test for homogeneity of multivariate dispersions 
PERMDISP (for statistical methods see below) was significant when including large bodied species (Group factor Trawling intensity: $\mathrm{F}=5.60, \mathrm{df}_{1}=3, \mathrm{df}_{2}=228, \mathrm{p}=0.0034$ ). Removing these species thus improved the statistical results by reducing heterogeneity of biomass.

A total of 29864 specimens belonging to 261 different taxa of benthic fauna were present in the samples.

\section{Multivariate analysis of macrofauna structure along the trawling intensity gradient}

Taking into consideration that the bottom trawling activities would be removed from the MPA, benthic fauna sampling stations was established inside and outside the MPA with the aim to cover a wide gradient in bottom trawling intensity (Fig. 1). The sampled stations were situated to cover the habitat and depths explored by the dominant demersal bottom trawl fisheries, and thus chosen within the depth interval $23-65 \mathrm{~m}$ where $95 \%$ of the trawled positions from the VMS of the dominant fisheries were located. Sampling stations were placed to reduce natural variation between habitats by limiting the stations to post glacial soft mud sediments according to sediment mapping of the Kattegat (Hallberg et al. 2010). In this design, we expect to identify macrofauna community shifts in the benthic community along the identified trawling intensity gradient.

All multivariate analyses were performed using the statistical package PERMANOVA + for PRIMER (Anderson et al. 2008). The effect of trawling intensity on the macrofauna community was analysed with PERMANOVA with trawling intensity at sampling station categorised into statistical quartiles $\left(<=0.4,>0.4<=2.1,>2.5<=4.6,>4.6 \mathrm{yr}^{-1}\right)$ as fixed factor. The categorisation was done to simplify interpretation of the results since two more factors 
was included in the design, and to standardise the trawling intensity gradient into informative

217 statistical groups representing low to high intensities. Year of sampling was fixed and

218 sampling station a random factor nested in trawling intensity. Community composition were

219 weighted both by abundance and biomass of species. Resemblance matrices were constructed

220 using Bray-Curtis similarity and abundance and biomass data was fourth root transformed to

221 reduce the influence of dominant species. Posthoc comparisons were done using pairwise

222 PERMANOVA, and results were visualized with Canonical Analysis of Principal Coordinates

223 (CAP). All data was evaluated for distance based test for homogeneity of multivariate

224 dispersions using the function PERMDISP.

226 To further explore the effect of the gradient in trawling intensity and to account for the

227 potential covariance of trawling intensity and depth related environmental factors known to be

228 important in the Kattegat (Petersen 1913, Rosenberg \& Möller 1979, Rosenberg et al. 2000,

229 Agrenius and Göransson 2009, Pommer et al. 2016, Leonardsson et al. 2016), we evaluated

230 depth together with trawling intensity as predictors for community composition weighted by

231 species abundance and biomass using Distance based Linear modelling (DistLM) and

232 Distance based redundancy analysis (dbRDA). The predictors were checked by draftsman

233 plots and trawling intensity was transformed by $\log (\mathrm{X}+1)$ and depth by square root to reduce

234 skewness. Depth and trawling intensity were checked for collinearity and a correlation of 0.64

235 was estimated for these variables. This is below the critical correlation level of 0.7 as

236 suggested by Dormann et al. (2013). The "Best" selection procedure was chosen together with

237 the selection criteria modified Akaike Information Criterion (AICc) for model selection, and

238 only predictor variables that were significant in marginal tests were selected. Individual

239 species contributing to the multivariate dbRDA model was evaluated using correlations

240 (Pearson's R) between species abundance and the axis that explained most of the variation 
241 correlating with trawling intensity. In addition, correlations were done between species

242 abundance and trawling intensity.

\section{Univariate analysis of macrofauna metrics along the trawling intensity gradient}

245 The effects of bottom trawling on macrofauna may be expected to depart from a linear

246 relationship. For this reason we analysed univariate response variables using generalized

247 additive models (GAMs). GAMs use non-parametric functions which allow to model non-

248 linear relationships without prior knowledge on their actual shape. The effect of trawling was

249 tested by applying GAM on the following univariate response variables: number of species

$250 N s p p$, total abundance Nind, total biomass Biom, abundance of the two dominant species

251 Amphiura filiformis and Amphiura chiajei, Richness index $d$ (Margalef 1958), Shannon

252 diversity $H^{\prime}\left(\log _{2}\right)$ (Shannon \& Weaver 1949) and Benthic Quality Index (BQI). BQI was

253 calculated according to Leonardsson et al. (2016) without the correction for depth as depth is

254 included in the GAM model (see below). The BQI is used by Sweden for benthic quality

255 assessments under the EU Water framework directive (2000/60/EC) and combines abundance

256 weighted species sensitivities with species diversity into one index. All the variables were

257 calculated at the level of individual sampling stations (i.e., for each year $y$ and geographical

258 location $\rho, \varphi$ identified by longitude and latitude degrees) and the analysis performed

259 accordingly. The models were formulated as follows:

$$
\operatorname{Response}_{(y, \rho, \varphi)} \sim \alpha_{y}+s\left(D_{(\rho, \varphi)}\right)+s\left(T I_{(y, \rho, \varphi)}\right)+s\left(\operatorname{Nind}_{(y, \rho, \varphi)}\right)+\gamma_{(\rho, \varphi)}+e_{(y, \rho, \varphi)}
$$

where $\alpha$ is the year specific intercept, $s$ is a one-dimensional (Wood 2004) smoothing function

264 on depth $(D)$ and trawling intensity $(T I)$. To account for dependency among sampling stations

265 which are closer in space, the error part of the model was separated into a Gaussian spatially 
autocorrelated component $(\gamma)$ (Venables and Ripley 2002, Dormann et al. 2007), which was treated as a random effect (Pinheiro and Bates 2000), and a normally distributed error term (e). The total abundance (Nind) was included as a predictor only for the model using Nspp as a response variable to account for changes in the detection probability of new species as abundance increases. Model overfitting was controlled by constraining to 3 the maximum degrees of freedom on the depth variable. Inspection of models' residuals revealed no major departure from the model assumptions of normality and homogeneity of variance. The GAM models were fitted using R and the library $m g c v$ (Wood 2011).

Effects of reduction in trawling intensity by the establishment of the marine protected area

In the evaluation of the closure for trawling within the MPA, we expected potential temporal changes in the macrofauna assemblage within the MPA to deviate from changes outside the MPA where trawling continues. No benthic sampling was carried out prior to the establishment of the MPA in 2009. However, we assume that the macrofauna community status of 2009 sampled five months after the enforcement of the MPA can be considered as a reasonable baseline since the impact of previous years bottom trawling was likely to remain longer (i.e. > 1.9 years) for macrofauna (Hiddink et al. 2017).

Samples were collected at the same stations in 2009, 2010, 2011 and 2014. Stations sampled within the MPA prior to the establishment in 2009 and outside over all the years, were defined as trawled if trawling intensities were above the median trawling intensity $(>=2.5)$ estimated from all sampling stations and the whole study period. As expected a reduction in trawling intensity by the establishment of the MPA in 2009 was seen over time. However, 
trawling intensity was not reduced to zero at all stations inside the MPA indicating some noncompliance or misclassification of vessels on transit at slow speed (Fig. S2).

The experimental effect of the MPA on the temporal development of the species assemblage was evaluated using PERMANOVA with year of sampling and treatment i.e. closure versus continuously trawled as fixed factors, and station as random factor nested in treatment. The effect of the closure on the macrofauna community will thus be the interaction between Year of sampling and Treatment (i.e. the "closed" area versus the area outside the MPA that was continuously "trawled"). Dependent variables examined were species composition weighted by abundance, biomass, or abundance of the two most dominant species (Amphiura filiformis and Amphiura chiajei), and univariate total abundance, total biomass and number of species. As significant effects were detected for the dominant species these were as well examined by a factorial ANOVA with the same design. Dependent variables i.e. abundances of the species were transformed by $\log \mathrm{X}+1$ and tested for unequal variances by Welsch's test. Univariate statistics were analysed using the statistical package JMP pro 12.0.1.

\section{RESULTS}

Multivariate analysis of macrofauna structure along the trawling intensity gradient

Trawling intensity estimated as swept area ratio ranged from $0-15 \mathrm{yr}^{-1}$ and was heavily skewed towards the lower range (median $2.1 \mathrm{yr}^{-1}$ ). The ranges and distributions of trawling intensity verified the stratification of the design and were stable over the four years sampled with the exception of the anticipated decrease at the 7 stations protected due to the establishment of the MPA from 2009 (Fig. S1 and S2, supplement). 
The PERMANOVA based on species abundance indicated significant effects of both year ( $p$

$317=0.0001)$ and trawling intensity $(p=0.0001)$ on the community composition of the

318 macrofauna, but no interaction between these two factors $(\mathrm{p}=0.0749$; Fig. 2). Pairwise

319 comparisons of trawling intensity effect showed that the effect of trawling intensity categories

320 differed between the overlapping two lower quartiles and the two highest overlapping

321 quartiles. Similar statistical results as for abundance were achieved using species biomass

322 without large bodied species (year: $\mathrm{p}=0.0001$; trawling intensity categorised into quartiles: $\mathrm{p}$

$323=0.0001$, and no interaction between these two factors: $p=0.1045)$. Pairwise comparisons of

324 trawling intensity categories again showed that the effect of trawling intensities differed

325 between the overlapping two lower quartiles and the two highest overlapping quartiles (for

326 details on statistics, see Supplement tables S1 on macrofauna abundance and table S2 on

327 biomass). The multivariate PERMANOVA analysis thus indicated that the macrofauna

328 assemblage was structured differently over the years and along the trawling intensity gradient

329 of the sampling stations, but that the effect of variation in trawling intensity did not change

330 over time.

332 To further explore the effect of the gradient in trawling intensity, depth together with trawling 333 intensity were evaluated as continuous predictors of community composition by Distance

334 based Linear modelling (DistLM) and Distance based redundancy analysis (dbRDA). Since

335 the year factor did not show interaction with trawling intensity in the foregoing

336 PERMANOVA analysis, data from all years were pooled to increase the generality of the

337 tests. The marginal test showed both trawling intensity and depth to be significant predictors

338 contributing to the model $(\log X+1$ trawling intensity $F=10.1, p=0.0001$, and square root

339 depth $\mathrm{F}=15.3, \mathrm{p}=0.0001)$. Using the best model selection procedure, i.e. all variable

340 combinations, and Akaike's Information Criterion with second order correction (AICc) both 
predictors were identified and explained together $7.4 \%$ of the variation in the community

342 composition. The Distance based redundancy analysis (dbRDA) visualise how the stations

343 with differing trawling intensity and depth relates to the multivariate dbRDA axes 1 and 2

344 (Fig. 3). Trawling intensity correlated with dbRDA 1 (multiple partial correlation 0.52) that

345 explained $6.4 \%$ of the total variation and to dbRDA $2(0.85)$ that explained $0.9 \%$ of the total

346 variation. Depth also correlated with both dbRDA 1 (multiple partial correlation 0.85 ) and

347 dbRDA 2 (0.52). The testing procedure above was also done using biomass of species as

348 dependent variable which showed the similar effects $(\log X+1$ trawling intensity $F=9.5, p=$

3490001 and square root depth $\mathrm{F}=14.5, \mathrm{p}=0.0001)$ and correlations to the dbRDA axis 1 and 2

350 (multiple partial correlation 0.52 and 0.86 respectively) and overall contribution to the total

351 variation 6.1 and $1 \%$. Depth also correlated with both dbRDA 1 (multiple partial correlation

352 0.86) and dbRDA $2(0.52)$.

354 Correlations between the multivariate ordination axis that explained most of the total

355 variation and abundance of individual species indicated that 40 macrofauna species had a

356 decreasing trend in abundance along the axis while 13 increased. Correlations between

357 individual species abundance and trawling intensity showed agreement with the species that 358 decreased along the axis for $58 \%$ of the species that had the negative trends e.g. Ampelisca 359 tenuicornis and Phoronis muelleri. For the species increasing $31 \%$ showed conformity with 360 the positive trend along e.g. Amphiura chiajei and Labidoplax buskii (Table 1).

362 Univariate analysis of macrofauna metrics along the trawling intensity gradient

364 Trawling intensity had a similar significant effect on the number of species, richness, 365 diversity and the benthic habitat quality (BQI), while its effect was non-significant on the 
total biomass and abundance of benthos (Fig. 4). The effect of trawling intensity was negative

367 for values below approx. $5 \mathrm{yr}^{-1}$, which include $64 \%$ of the sampling stations, and the

368 relationship became slightly positive for larger values. Depth had no significant effect in all

369 the models with the exception of the benthos abundance which significantly decreased $(\mathrm{p}<$

370 0.01) in response to increasing depth until approximately $40 \mathrm{~m}$ (Fig. 4). The GAM model of

371 the number of species has a $\mathrm{R}^{2}$ value of 0.34 . In the other models the $\mathrm{R}^{2}$ ranged between 0.10

372 and 0.19 with the exception of the model on biomass which had a value of 0.015 (Table 2).

374 The soft mud macrofauna community in the area investigated was dominated by the

375 burrowing brittle stars Amphiura filiformis and Amphiura chiajei. Together these two species 376 represented $50 \%$ in the overall number of individuals, and $58 \%$ of the biomass. A. filiformis

377 was present in $98 \%$ and $A$. chiajei in $83 \%$ of the samples. The two species presented an 378 opposite response to depth below $40 \mathrm{~m}$, with $A$. chiajei increasing in deeper waters while $A$.

379 filiformis decreasing in abundance in the same depth range (Fig. 5). The response to trawling 380 intensity was non-significant for A. filiformis but positive for A. chiajei at low to medium 381 trawling intensities and decreased only for trawling intensity levels above $5 \mathrm{yr}^{-1}$.

Effects of reduction in trawling intensity by the establishment of the marine protected

area

385 To evaluate the potential recovery of the macrofauna within the MPA we hypothesized that 386 the temporal development of the macrofauna within the MPA deviate from the area outside 387 where trawling continued. Multivariate PERMANOVA tests of abundance and biomass and 388 univariate tests with PERMANOVA number of species (Fig. 6a), total abundance (Fig. 6b) 389 and total biomass (Fig. 6c) showed no interactions between the year and treatment (Table S3).

390 However, abundance of the dominating species (A. chiajei and A. filiformis) showed a 
significant interaction between the factors treatment and year (Table S4 and 5). Post-hoc comparison with pairwise PERMANOVA indicated that the last year 2014 differed from the earlier years 2009 - 2011 within the closed area, while no difference between years occurred

in the area where trawling continued. Examining the pattern with factorial ANOVA indicated the same interaction with a decrease for both species within the closed area in 2014 compared to earlier years and no temporal trend within the trawled area (Fig. 7), however, only at a significance level of $\alpha=0.10$.

\section{DISCUSSION}

In this study, we found shifts in the structure of the macrofauna community in soft mud substrate along a wide gradient in trawling intensity. We investigated this using a stratified sampling design covering a wide and precisely estimated gradient in bottom trawling intensity, taking the establishment of a marine protected area (MPA) into account to ensure as far as possible that untrawled as well as intensively trawled sites were included in the gradient. Our results show small but significant shifts in community composition and a decrease in number of species and indices of diversity as trawling intensity increases from low to medium levels i.e. below $5 \mathrm{yr}^{-1}$. Several taxa had a negative trend along the gradient of increasing trawling intensity while a few taxa increased. The dominant brittle star species showed different responses as Amphiura chiajei increased at low to medium trawling intensities and decreased only at trawling intensity above $5 \mathrm{yr}^{-1}$, while Amphiura filiformis showed no conclusive response. Effects along the trawling intensity gradient were non-linear and in general more evident at the lower range. Responses for number of species and diversity indices appear inverted at high levels of trawling intensity, but the large confidence intervals related to the low number of observations suggest high uncertainty of the model to explain the 
416 effect of fishing intensity at the high end of the range. There was temporal change to the

417 benthic community over the duration of the study, but the effect of trawling intensity on the

418 benthos was consistent over time. As expected, the macrofauna community was also

419 structured according to depth which was included in the statistical models to avoid

420 confounding effects.

422 In a study similar to ours, Pommer et al. (2016) concluded that nearly $100 \%$ of the habitats

423 below $22 \mathrm{~m}$ in the Kattegat were impacted by bottom trawling, and their analysis could not

424 discriminate between effects on the macrofauna in lightly trawled versus heavily trawled

425 areas. Differences between the studies can be explained by higher spatial resolution of

426 trawling intensity in our study in combination with the use of the MPA to ensure that

427 sampling was done across a wide range of trawling intensity to detect effects by bottom

428 trawling on the benthic macrofauna. In another similar study of otter trawl disturbance at $N$.

429 norvegicus soft sediment fishing grounds in the Irish Sea, Hinz et al. (2009) found negative

430 effects of trawling intensity on macrofauna abundance, number of species and total biomass.

431 Similar ranges of trawling intensities were observed by Hinz et al. (2009) and in our study

432 (maximum 18.2 in the Irish Sea and $15.8 \mathrm{yr}^{-1}$ in our study), however, in the Irish Sea

433 comparable stations with trawling intensity below $1.3 \mathrm{yr}^{-1}$ could not be identified while our

434 study included low ranges and untrawled comparable conditions in the MPA. The species

435 decreasing with trawling intensity show some commonalities between the two studies for the

436 following taxa: the Phoronida Phoronis sp., crustacean amphipods of the genus Ampelisca

437 and the polychaete Magelona alleni, however, also contradicting results in that the

438 dominating brittle star A. filiformis appears tolerant to bottom trawling in our study while

439 decreased in response to trawling in the Irish Sea. In explaining the differences, we emphasize

440 the need to consider non-linear effects, detailed spatial estimates of trawling intensity, and 
again the necessity of including untrawled and lightly trawled conditions in gradient studies

442 as effects are most prominent at low levels of the gradient. The most sensitive species are

443 likely affected and depleted already at low trawling intensities, and the benthic fauna left are

444 the more resilient species (National Research Council 2002). Our results support this pattern

445 of response as the macrofauna composition and the decrease in number of species and indices

446 of diversity is evident mainly at the lower range of trawling intensity.

448 However, our results differ from other studies (e.g. Hiddink et al. 2006, Hintz et al. 2009, 449 Reiss et al. 2009, Hiddink et al. 2011, Johnson et al. 2015) in that we could not detect any 450 shifts in total biomass. A possible explanation to this difference might be that in our study, 451 one of the two dominant species $A$. chiajei increased along the trawling intensity gradient 452 which may then mask the decrease in other less common species negatively affected. Reiss et 453 al. (2009) in their study of beam trawling impact on macrofauna communities found that even 454 in areas of high trawling disturbance, further increase still caused additional damage to the 455 faunal communities in terms of biomass and number of species. The ground-gear used in 456 beam trawling penetrate the seafloor deeper than otter trawling (Eigaard et al. 2016), which 457 might explain the different responses between our study and others where beam trawling is 458 common (e.g. Hiddink et al. 2006, Reiss et al. 2009). However, all these other studies 459 analysed the effect of trawling intensity using much coarser spatial resolutions (approximately $4601 \mathrm{X} 1 \mathrm{~nm}$ or larger) compared to our analysis making the studies difficult to compare.

462 It is crucial to assess the spatial distribution of bottom trawling intensity at a fine resolution if 463 the aim of impact studies is to cover long term impact and effects of direct disturbance on the 464 seafloor. This is because relationships between trawling and responses might otherwise be 465 confounded by misclassification of the pressure at the site where the impact is monitored. 
Our study had access to reliable raw VMS data and logbooks from all the nations fishing in

467 the area i.e. Sweden and Denmark, and was thus able to reconstruct with high precision the daily bottom trawling intensity at each station sampled for benthic macrofauna from 2006 to 2014. The VMS derived effort is considered to be an underestimate since vessels smaller than $15 \mathrm{~m}$ was not included in the gradient. However, we consider the gradient established to be

471 reliable since the main fishing grounds for trawlers in the Kattegat are expected to be similar

472 for large and small vessels without VMS due to the large coverage of the soft mud habitat, 473 and that the smaller trawlers target the same species composition as the larger fleet.

474 Differences in compliance between small and large vessels, however, may have introduced 475 bias in the estimates of trawling intensity within the MPA due to the lack of VMS monitoring 476 of smaller vessels. The examination of the trend over time within the closed area indicate only 477 a decrease over time for the dominating brittle star species. Non-compliance during the two 478 first year after enforcement of the MPA is evident as the VMS indicate rather high activity. 479 This might explain the lacking of a response over time for the macrofauna community over 480 the relatively short period studied following the closure.

482 The choice of grid cell and resolution will always be a trade-off with the risk of mismatch 483 between the direct impact at each sampling location and the patchiness of the trawling 484 pressure. In this study, we used a fine scale search radius to the stations studied as we 485 prioritized to capture and be able to ascertain the low-end part of the trawling intensity 486 gradient, i.e. lightly or untrawled areas within the Kattegat Nephrops fishing ground.

487 However, it is unclear whether the indirect ecological disturbance by bottom trawling acting 488 on macrofaunal assemblages, e.g. due to shifts in predator-prey relationships (van Denderen 489 et al. 2013, Hiddink et al. 2016) will be larger than the direct localized physical disturbance 490 by a single trawl path. Response curves to trawling intensity from indirect effects may further 
differ both in shape and trigger levels as these impacts might act on larger temporal and

492 spatial scales. Impacts might reflect how the communities connect to each other and how fast animals can recolonize an impacted site either by migration or recruitment of new animals, as discussed by Lambert et al. (2012) who found the most significant relationships between spatial resolution of $2 \mathrm{~km}$ by $2 \mathrm{~km}$ to $4 \mathrm{~km}$ by $4 \mathrm{~km}$ which represents a 20 - 80 times coarser 496 cell resolutions than this study.

498 It should to be considered that even though our study included stations within the MPA that 499 had not been trawled for 5 years, stations with pristine conditions were not represented. We 500 could not find any trend in the macrofauna community indicating recovery within the closed 501 area, possibly due to the short period of time since the MPA was established and the lack of 502 compliance by the fleet during the first two years following enforcement of the MPA. Taking 503 a longer historical perspective, the trawl fishery in the Kattegat was likely more widespread 504 when the fishery targeted cod Gadus morhua before quotas were severely enforeced around 505 year 2000. However, no reliable VMS data coupled to logbooks is available before 2005 to 506 support this statement. Also, the Kattegat is a eutrophicated coastal sea area that had recurrent 507 problems of oxygen deficiency mainly in the 1980's which resulted in large areas with 508 mortality of benthic invertebrates (Rosenberg \& Loo, 1988, Baden et al. 1990). The large 509 number of stations sampled, however, allows historical comparison of the macrofauna 510 community sampled in the early 1900's. Around this time, when industrial trawling started, 511 Petersen (1913) made extensive quantitative benthic macrofauna mapping of the Kattegat that 512 showed differences but also large similarities with the assemblages observed today, e.g. large 513 areas dominated by the brittle stars Amphiura spp. Pearson et al. (1985) re-assessed Petersen's 514 stations in the Kattegat and found generally higher abundances and biomass, and that $A$. 515 filiformis had increased in dominance at over $70 \%$ of the stations compared. Also, in the 
516 beginning of the 1900's, a large area in the south-eastern Kattegat was dominated by

517 amphipods i.e. the Haploops community which has not been found again in the area

518 following revisits (Göransson 1999). Only 15 specimens of Haploops spp. were noted in four

519 of our samples within the historical main distribution area of these species. Petersen (1913),

520 in contrast reported thousands of individuals per $\mathrm{m}^{-2}$ at the beginning of the century. Several

521 other species were described to be associated to Petersens Haploops community, including

522 the brittle star Ophiura robusta, the clams Pseudamussium peslutrae and Limea loscombi, the

523 ostracod Philomedes brenda, the bivalves Nuculana pernula and Nuculana minuta and the

524 brittle stars Ophiura albida and Ophiocten affinis (Petersen 1913, Göransson 2002,

525 Göransson et al. 2010). Several of these species were noted at a few stations in our study

526 between but in comparably low numbers, and the species $O$. robusta, P. peslutrae and $L$.

527 loscombi were not found at all in the investigated area. Oxygen deficiency and bottom

528 trawling has been put forward as possible explanations to the disappearance of Haploops and

529 shift in species assemblages (Göransson 1999). Interestingly, in a study from the southern

530 hemisphere in New Zealand, a similar shift in macrofaunal assemblages have been described

531 (Handley et al. 2014). In that study amphipods, ostracods and bivalves numerically dominated

532 soft mud communities within a relatively pristine untrawled protected area, while nearby

533 trawled comparable mud habitats were dominated by burrowing brittle stars (Amphiura sp.)

534 and polychaetes. In summary, our results confirm the disappearance of dense Haploops

535 dominated communities in the Kattegat and supports that bottom trawling contribute to the

536 shift towards brittle star dominated communities since the two Amphiura species were

537 tolerant to bottom trawling, and that $A$. chiajei increased in abundance at low to medium

538 trawling intensities. 
The Amphiura species dominate abundance and biomass over large areas in the Kattegat,

541 Skagerrak and the North Sea with localized maxima of $>1000$ ind. $\mathrm{m}^{-2}$ (Duineveld et al. 1986,

542 Gogina et al. 2016). Given that this distribution coincides with areas fished extensively by

543 bottom trawls (Eigaard et al. 2016b, and this study), it is evident that these two species are

544 resilient to trawling. Characteristic traits for these brittle stars are that they have planktonic

545 larvae with great dispersal capability, are burrowed with their disc $\mathrm{ca} 5 \mathrm{~cm}$ in the sediments

546 with their arms protruding above the sediment surface, and frequently autotomize their arms

547 or even discs in A. filiformis, as a response to attacks from predators (Sköld et al. 1994). Their

548 arm regeneration potential is great but differ considerably between the two species in that $A$.

549 filiformis regenerate an arm about 5 times faster than A. chiajei (Sköld \& Gunnarsson 1996).

550 Both species are deposit feeders and A. filiformis is also a facultative suspension feeder (Loo

551 et al. 1996, Solan \&Kennedy 2002). Populations are often stable, comprised of adults and

552 longevity has been estimated to more than 20 years (O'Connor et al. 1983). The frequency of

553 sub-lethal predation can be assessed by counting scars on arms of brittle stars (Aronson

554 1989), and differences have been documented between species and among trawled versus

555 untrawled areas, with lower incidence of scars of $A$. filiformis in trawled areas in the

556 Skagerrak - Kattegat (Sköld \& Rosenberg 1996). Mechanical damage of ophiuroid arms by

557 trawling have not been investigated, however, storms do not appear to cause arm damage in

558 brittlestar populations on tropical reefs, and predation is considered to be the prime source of

559 arm injuries (Aronson, 1991). Important predators of Amphiura spp. are demersal fish species

560 and crustaceans, e.g., haddock Melanogrammus aeglefinus, dab Limanda limanda, American

561 plaice Hippoglossoides platessoides, plaice Pleuronectes platessa and Norway lobster

562 Nephrops norvegicus (Duineveld \& Van Noort, 1986, Baden et al, 1990, Mattson, 1992, Pihl,

563 1994, Kaiser \& Ramsey 1997, Hiddink et al. 2016). Fishing effort is intense and stable in the

564 fishing grounds examined and targeted as well as by-catches of the above listed predators are 
significant (Hornborg et al. 2016). In addition, some of these predators are stationary, in

566 particular N. norvegicus in its adult stages. We thus conclude that reduced predation pressure

567 due to local depletion of these predators at fished stations may be one important mechanism

568 behind the increase of $A$. chiajei along the trawling intensity gradient. The examination of the

569 trend over time within the closed area supports this conclusion as the dominating species i.e.

570 both Amphiura species., indicate a decrease over time which could be due to increased

571 abundance of fish and Nephrops following cessation of the fishery and accordingly increased

572 local predation pressure.

573

574 Several indirect effects of bottom fishing on fish and vice versa have been documented

575 (Collie et al. 2016), and studies from the Irish sea (Hiddink et al. 2011, Johnson et al. 2015),

576 and the Kattegat (Hiddink et al. 2016) at soft seafloor otter trawl fishing grounds link the

577 chronic trawling effects to the condition of predators, and explain the results as responses to

578 the ratio of prey to predator biomass and dietary shifts. Our study emphasizes the complex

579 interplay between predators, their benthic prey and the interaction with bottom trawling.

580 Amphiura spp. have their arms protruding above the sediment surface when feeding and arms

581 are frequently preyed on by fish and Nephrops. As these heavily fished predators are locally

582 removed by trawling, Amphiura spp. being released from predation causes its population to

583 grow. That is, if predators are more strongly affected than their prey by bottom trawling, prey

584 may increase with bottom trawling until trawling becomes so intense that the prey is also

585 affected.

587 Conclusion

588 Our results show shifts in the macrofauna assemblage and a decrease in number of species 589 and indices of diversity at low to medium trawling intensities. The dominant brittle stars $A$. 
filiformis and $A$. chiajei are evidently resistant to trawling at low to intermediate intensities

591 and $A$. chiajei showed positive response to increasing trawling intensity possibly caused by

592 reduction in predation by demersal fish and the target species $N$. norvegicus. Furthermore, the

593 study contributes to the understanding of how chronic bottom trawling contribute to the

594 documented historical shifts in benthic macrofauna assemblages of soft seafloors by reducing

595 diversity and benefitting resistant species like brittle stars. The Kattegat is representative for

596 similar soft seafloor coastal and shelf areas exploited by bottom otter trawl fisheries for fish

597 and crustaceans. The large MPA provides a unique potential for further studies of recovery of

598 the benthic fauna following cessation of bottom trawling.

599

600 Acknowledgements

601

602 We thank 4 anonymous reviewers for critical and fruitful comments on the manuscript. The

603 EUFP7 project "BENTHIS" (grant 693 agreement number 312088) and the Swedish agency

604 for marine and water management, SwAM (Dnr 74915 and 482113) funded the research. VB

605 and PJ were partially funded by the Swedish Research Council Formas, grant no. 2012942.

606 The benthic sampling was financed by SWaM and the County Administration of Halland,

607 Sweden.

608

609 LITERATURE CITED

610 Agrenius S, Göransson P (2009) Kattegatts bottenfauna har förändrats. Havet 2009: 48-50 (in

611 Swedish)

612

613 Anderson MJ, Gorley RN, Clarke KR (2008) PERMANOVA + for PRIMER: Guide to

614 software and statistical methods. PRIMER - E: Plymoth, UK 
616 Andersson L, Rydberg L (1988) Trends in nutrient and oxygen conditions within the

617 Kattegat: effects of local nutrient supply. Estuar Coast Shelf Sci 26: 559-579

618

619 Aronson RB (1989) Brittlestar beds: low predation anachronisms in the British 1sles Ecol 70:

$620 \quad 856-865$

621

622 Aronson, RB (1991) Predation, physical disturbance, and sublethal arm damage in

623 ophiuroids: a Jurassic-Recent comparison. Mar Ecol Prog Ser 74: 91-97

624

625 Baden SP, Loo LO, Pihl L, Rosenberg R (1990) Effects of eutrophication on benthic

626 communities including fish: Swedish West Coast. Ambio 19: 113-122

627

628

Bartolino V, Cardinale M, Svedäng H, Casini M, Linderholm HW, Grimwall A (2012)

629 Historical spatiotemporal dynamics of eastern North Sea cod. Can J Fish Aquat Sci 69: 833$630 \quad 841$

631

632 Bastardie F, Nielsen JR, Ulrich C, Egekvist J, Degel H (2010) Detailed mapping of fishing

633 effort and landings by coupling fishing logbooks with satellite recorded vessel geolocation.

634 Fish Res 106: doi:10.1016/j.fishres.2010.06.016

635

636 Bergström U, Sköld M, Wennhage H, Wikström A (2016). Ekologiska effekter av fiskefria

637 områden i Sveriges kust- och havsområden. Aqua Reports 2016:20. Institutionen för

638 akvatiska resurser, Sveriges lantbruksuniversitet, Öregrund. 207 pp. (In Swedish).

639 
640 Collie, JS, Hall, SJ, Kaiser, MJ, Poiner, IR (2000) A quantitative analysis of fishing impacts

641 on shelfsea benthos. J Anim Ecol 69: 785-798

642

643 Collie, J, Hiddink, JG, van Kooten, T, Rijnsdorp, AD, Kaiser, MJ, Jennings, S Hilborn, R

644 (2016) Indirect effects of bottom fishing on the productivity of marine fish. Fish and

645 Fisheries: DOI: 10.1111/faf.12193

646

647

van Denderen PD, van Kooten T, Rijnsdorp, AD (2013) When does fishing lead to more fish?

648 Community consequences of bottom trawl fisheries in demersal food webs. Proc R Soc B

649 280: $20131883 \mathrm{http} / / / \mathrm{dx}$. doi.org/10.1098/rspb.2013.1883

650

651 van Denderen, PD, Bolam, SG, Hiddink, JG, Jennings, S, Kenny, A, Rijnsdorp, AD, van

652 Kooten, T (2015) Similar effects of bottom trawling and natural disturbance on composition

653 and function of benthic communities across habitats. Mar Ecol Prog Ser 541: 31-43

654

655 Dormann CF, McPherson JM, Araujo MB, Bivand R, Bolliger J, Carl G, Davies RG,

656 Hirzel A, Jetz W, Kissling WD, Kühn I, Ohlemüller R, Peres-Neto PR,

657 Reineking B, Schröder B, Schurr FM, Wilson (2007) Methods to account for spatial

658 autocorrelation in the analysis of species distributional data: a review. Ecography 30: 609-628

659

660 Dormann CF, Elith J, Bacher S, Buchmann CM, Carl G, Carré G, García Marquéz JR, Gruber 661 B, Lafourcade B, Leitão PJ, Münkemüller T, McClean C, Osborne P, Reineking B, Schröder

662 B, Skidmore A, Zurell D, Lautenbach S (2013) Collinearity: a review of methods to deal with 663 it and a simulation study evaluating their performance. Ecography 36(1): 27-46

664 
Dounas C, Davies I, Triantafyllou G, Koulouri P, Petihakis G, Arvanitidis C, Sourlatzis G

666 Eleftheriou A (2007) Largescale impacts of bottom trawling on shelf primary productivity.

667 Cont Shelf Res 27(17): 2198-2210

668

669 Duineveld GCA, Van Noort, GJ (1986) Observations of the population dynamics of 670 Amphiura filiformis (Ophiuroidea: Echinodermata) in the southern North Sea and its

671 exploitation by the dab, Limanda limanda. Neth J Sea Res 20: 8594

672

673 Eigaard OR, Bastardie F, Breen M, Dinesen GE, Hintzen NT, Laffargue P, Mortensen LO,

674 Nielsen JR, Nilsson HC, O’Neill FG, Polet H, Reid DG, Sala A, Sköld M, Smith C, Sørensen

675 TK, Tully O, Zengin M, Rijnsdorp A D (2016a) Estimating seabed pressure from demersal

676 trawls, seines, and dredges based on gear design and dimensions. ICES J Mar Sci

677 doi:10.1093/icesjms/fsv099E

678

679 Eigaard OR, Bastardie F, Hinzen NT, Buhl-Mortensen L, Mortensen PB, Catarino R, Dinesen

680 GE, Egekvist J, Fock H, Geitner K, Gerritsen H, González MM, Jonsson P, Kavadas S,

681 Laffargue P, Lundy M, Gonzalez-Mirelis G, Nielsen JR, Papadopoulou N, Posen PE,

682 Pulcinella J, Russo T, Sala A, Silva C, Smith CJ, Vanelslander B, Rijnsdorp AD (2016b) The

683 footprint of bottom trawling in European waters: distribution, intensity, and seabed integrity.

684 ICES J Mar Sci doi: 10.1093/icesjms/fsw194

685

686 Fosså JH, Mortensen PB, Furevik DM (2002) The deep-water coral Lophelia pertusa in

687 Norwegian waters: distribution and fishery impacts. Hydrobiol 471(1-3): 1-12

688 
689 Gogina M, Nygård H, Blomqvist M, Daunys D, Josefson AB, Kotta J, Maximov A, Warzocha

690 J, Yermakov V, Gräwe U, Zettler ML (2016) The Baltic Sea scale inventory of benthic faunal 691 communities. ICES J Mar Sci 73 (4): 1196-1213 10.1093/icesjms/fsv265

692

693 Granéli W (1992) Below-halocline oxygen consumption in the Kattegat. Hydrobiol 235/236:

$694 \quad 303-310$

695

696 Greathead CF, Donnan DW, Mair JM, Saunders GR (2007) The sea pens Virgularia

697 mirabilis, Pennatula phosphorea and Funiculina quadrangularis: distribution and

698 conservation issues in Scottish waters. J Mar Biol Ass UK 87: 1095-1103

699

700 Gray JS, Dayton P, Thrush S, Kaiser MJ (2006) On effects of trawling, benthos and sampling 701 design. Mar Pollut Bull 52(8): 840-843

702

703

Göransson P (1999) Det långa och det korta perspektivet i södra Kattegatt - bottendjurens

704 berättelser från två provpunkter. Fauna och Flora 94:3 125-138 (In Swedish)

705

706 Göransson P (2002) Petersen’s benthic macrofauna stations revisited in the Öresund area

707 (southern Sweden) and species composition in the 1990's - signs of decreased biological

708 variation. Sarsia 87: 263-280

709

710 Göransson P, Bertilsson Vuksan S, Karlfelt J, Börjesson L (2010) Haploops samhället och

711 Modiolus samhället utanför Helsingborg 2000 - 2009. Report to Environmental Board of

712 Helsingborg 2010 (In Swedish)

713 
714 Hallberg O, Nyberg J, Elhammer J, Erlandsson C, (2010) Ytsubstratklassning Av

715 Maringeologisk Information. SGU Rapport: Dnr 08-1565/2009 Rapport Maringeologi Nr $716 \quad 2010: 1$ (in Swedish)

718 Handley SJ, Willis TJ, Cole R G, Bradley A, Cairney DJ, Brown SN, Carter ME (2014) The 719 importance of benchmarking habitat structure and composition for understanding the extent of 720 fishing impacts in soft sediment ecosystems. J Sea Res 86: 58-68

722 Hiddink JG, Jennings S, Sciberras M, Szostek CL, Hughes KM, Ellis N, Rijnsdorp AD, 723 McConnaughey RA, Mazor T, Hilborn R, Collie JS, Pitcher CR, Amoroso RO, Parma AM, 724 Suuronen P, Kaiser MJ (2017) Global analysis of depletion and recovery of seabed biota after 725 bottom trawling disturbance. Proc Nat Ac Sci 114: 8301-8306

Hiddink JG, Jennings S, Kaiser MJ, Queirós AM, Duplisea DE, Piet GJ (2006) Cumulative impacts of seabed trawl disturbance on benthic biomass, production, and species richness in different habitats. Can J Fish Aquat Sci 63:721-736

Hiddink JG, Johnson AF, Kingham R, Hinz H (2011) Could our fisheries be more productive? Indirect negative effects of bottom trawl fisheries on fish condition. J Appl Ecol 48:1441-1449

734

Hiddink JG, Moranta J, Balestrini S, Sciberras M, Cendrier M, Bowyer, Kaiser MJ, Sköld M, 736 Jonsson P, Bastardie F, Hinz H (2016) Bottom trawling affects fish condition through changes

737 in the ratio of prey availability to density of competitors. J App Ecol doi: 
740 Hinz H, Prieto V, Kaiser MJ (2009) Trawl disturbance on benthic communities: chronic

741 effects and experimental predictions. Ecol Appl 19: 761-773

742

743 Hintzen NT, Piet GJ, Brunel T (2010) Improved estimation of trawling tracks using cubic

744 Hermite spline interpolation of position registration data. Fish Res 101(1): 108-115

746 Hintzen NT, Bastardie F, Beare D, Piet GJ, Ulrich C, Deporte N, Egekvist J, Degel H

747 (2012) VMStools: Opensource software for the processing, analysis and visualisation of

748 fisheries logbook and VMS data. Fish Res 115: 31-43

749

750 Hornborg S, Ulmestrand M, Sköld M, Jonsson P, Valentinsson D, Eigaard OR, Feekings JP,

751 Nielsen JR, Bastardie F, Lövgren J (2016) New policies may call for new approaches: the

752 case of the Swedish Norway lobster (Nephrops norvegicus) fisheries in Kattegat and

753 Skagerrak. ICES J Mar Sci doi: 10.1093/icesjms/fsw153

754

755 ICES (2015) Report of the Working Group for the Assessment of Demersal Stocks in the

756 North Sea and Skagerrak (WGNSSK), 28 April-7 May 2014, ICES HQ, Copenhagen,

757 Denmark. ICES CM 2015/ACOM:13 1031 pp

758

759 ICES (2016) OSPAR request for further development of fishing intensity and pressure

760 mapping ICES advice 2016, Book 1 ICES Special Request Advice

761 www.ices.dk/sites/pub/Publication\%20Reports/Advice/2016/Special_Requests/OSPAR_furth

762 er_development_of_fishing_intensity_and_pressure_mapping.pdf 
764 Johnson AF, Gorelli G, Jenkins SR, Hiddink JG, Hinz H (2015) Effects of bottom trawling on

765 fish foraging and feeding. Proc R Soc B 282: 20142336

766

767 de Juan S, Demestre M (2012) A Trawl Disturbance Indicator to quantify large scale fishing

768 impact on benthic ecosystems. Ecol Ind 18:183-190

769

770 Jørgensen LL, Planque B, Thangstad TH, Certain G (2016) Vulnerability of megabenthic

771 species to trawling in the Barents Sea. ICES J Mar Sci 73 (suppl 1): i84-i97 doi:

772 101093/icesjms/fsv107

773

774 Kaiser MJ, Ramsey K (1997) Opportunistic feeding by dabs within areas of trawl disturbance:

775 possible implications for increased survival. Mar Ecol Prog Ser 152: 307-310

776

777 Kaiser MJ, Clarke KR, Hinz H, Austen MCV, Somerfield PJ, Karakassis I (2006) Global

778 analysis of response and recovery of benthic biota to fishing. Mar Ecol Prog Ser 311: 1-14

779

780 Lambert GI, Jennings S, Hiddink JG, Hintzen NT, Hinz H, Kaiser MJ, Murray LG (2012)

781 Implications of using alternative methods of vessel monitoring system (VMS) data analysis to

782 describe fishing activities and impacts ICES J Mar Sci 69: 682-693

783

784 Leonardsson K, Blomqvist M, Rosenberg R (2016) Reducing spatial variation in

785 environmental assessment of marine benthic fauna. Mar Pollut Bull 104, 129138 Doi:

786 101016/jmarpolbul201601050

787 
Loo LO, Jonsson PR, Sköld M, Karlsson Ö (1996) Passive suspension feeding in Amphiura

789 filiformis (Echinodermata: Ophiuroidea): feeding behaviour in flume flow and potential 790 feeding rate of field populations. Mar Ecol Prog Ser 139: 143-155

791

792 Løkkeborg S (2005) Impacts of trawling and scallop dredging on benthic habitats and 793 communities. Fisheries Technical Paper No. 472 FAO, Rome 58 pp

794

795 Margalef R (1958) Information theory in ecology. Int J Gen Syst 3: 36-71

796

797 Mattson S (1992) Food and feeding habits of fish species over a sublittoral bottom in the 798 North-east Atlantic 3 Haddock (Melanogrammus aeglefinus (L)) (Gadidae) Sarsia 77: 33-45 799

800 National Research Council (2002) Committee on Ecosystem Effects of Fishing: Phase 1 801 Effects of trawling and dredging on seafloor habitat National Academy Press, Washington, 802 DC

803

804 O'Connor B, Bowmer T, Grehan A (1983) Long-term assessment of the population dynamics 805 of Amphiura filiformis (Echinodermata: Ophiuroidea) in Galway Bay (west coast of 1reland). Mar Biol 75: 279-28

807

808 Pearson TH, Josefson A, Rosenberg R (1985) Petersen's benthic stations revisited I Is the 809 Kattegat becoming eutrophic? J Exp Mar Biol Ecol 92: 157-206

810

811 Petersen CGJ (1913) Havets bonitering II Om havbundens dyresamfund og disses betydning 812 for den marine zoogeografi. Den danske biologiske station XXI Kjøbenhavn 1913 (in Danish) 
814 Pihl L (1994) Changes in the diet of demersal fish due to eutrophication-induced hypoxia in

815 the Kattegat, Sweden. Can J Fish Aquat Sci: 51: 321-336

816

817 Pinheiro JC, Bates DM (2000) Mixed-Effects Models in S and S-PLUS. Springer, New York, 818 NY

819

820 Pommer CD, Olesen M, Hansen JLS (2016) Impact and distribution of bottom trawl fishing 821 on mud-bottom communities in the Kattegat. Mar Ecol Prog Ser 548: 47-60

822

823 Reiss H, Greenstreet SPR, Sieben K, Ehrich S, Piet GJ, Quirijns F, Robertson L, Wolff

824 WJ, Kröncke I (2009) Effects of fishing disturbance on benthic communities and secondary

825 production within an intensively fished area. Mar Ecol Prog Ser 394: 201-213

826

827 Rosenberg R, Loo LO (1988) Marine eutrophication induced oxygen deficiency: effects on

828 soft benthic fauna, western Sweden. Ophelia 29: 213225

829

830 Rosenberg R, Möller P, (1979) Salinity stratified benthic macrofaunal communities and

831 long-term monitoring along the west coast of Sweden. J Exp Mar Biol Ecol 37:

$832 \quad 175-203$

833

834 Rosenberg R, Nilsson HC, Hellman B, Agrenius S (2000) Depth correlated benthic faunal

835 quantity and internal burrow structures on the slopes of a Marine Depression. Est Coast Shelf

836 Sci 50(6): $843-853$

837 
838 Shannon CE, Weaver W, (1949) The Mathematical Theory of Communication. University of

839 Illinois Press, Urbana

840

841 Sköld M, Gunnarsson JSG (1996) Somatic and germinal growth of the infaunal brittle stars

842 Amphiura filformis and A chiajej in response to organic enrichment. Mar Ecol Prog Ser

$843 \quad 142: 203-214$

844

845 Sköld M, Loo LO, Rosenberg R (1994) Production. dynamics and demography of an

846 Amphiura filiformis population. Mar Ecol Prog Ser 103:81-90

847

848 Sköld M, Rosenberg R (1996) Arm regeneration frequency in eight species of Ophiuroidea

849 (Echinodermata) from European sea areas. J Sea Res 35: 353-362

850

851 Solan M, Kennedy R (2002) Observation and quantification of in situ animal - sediment

852 relations using time-lapse sediment profile imagery (t-SPI). Mar Ecol Prog Ser 43: 143-156

853

854 Thrush S, Hewitt J, Cummings V, Dayton P, Cryer M, Turner S (1998) Disturbance of the

855 marine benthic habitat by commercial fishing: impacts at the scale of the fishery. Ecol Appl 8:

$856 \quad 866-879$

857

858 Tillin HM, Hiddink JG, Jennings S, Kaiser MJ (2006) Chronic bottom trawling alters the

859 functional composition of benthic invertebrate communities on a seabasin scale. Mar Ecol

$860 \quad$ Prog Ser 318: 3145

861 
862 Tjensvoll I, Kutti T, Fosså JH, Bannister RJ (2013) Rapid respiratory responses of the deep-

863 water sponge Geodia barretti exposed to suspended sediments. Aquat Biol 19: 65-73.

864

865 Venables WN, Ripley BD (2002) Modern Applied Statistics with S. Springer, New York, NY 866

867 Vitale F, Börjesson P, Svedäng H, Casini M (2008) The spatial distribution of cod (Gadus

868 morhua L.) spawning grounds in the Kattegat, eastern North Sea. Fish Res 90: 36-44

869

870 Wood S (2004) Stable and Efficient Multiple Smoothing Parameter Estimation for 871 Generalized Additive Models. J Am Stat Assoc 99: 673-686

872

873 Wood S (2011) Fast stable restricted maximum likelihood and marginal likelihood estimation

874 of semiparametric generalized linear models. J Roy Stat Soc (B) 73: 3-36

875 
878 Table 1. Linear trends of individual species abundance in relation to ordination along axis

879 dbRDA 1 that best contributed to the total variation $(6.4 \%)$ and correlate with Trawling

880 intensity (0.52). Correlations between species abundance and trawling intensity are given

881 within brackets. Only significant correlations with the dbRDA axis 1 are shown i.e., Pearson

882 correlation coefficient $\mathrm{R}>=0.14, \mathrm{df}=252, \mathrm{p}<0.05$.

\begin{tabular}{|c|c|c|c|c|}
\hline \multirow{3}{*}{$\begin{array}{l}\text { Species decreasing with } \\
\text { trawling intensity and axis } \\
\text { dbRDA } 1\end{array}$} & \multicolumn{4}{|c|}{ Species increasing with } \\
\hline & & trawling intensity and axis & & \\
\hline & $\mathrm{R}$ & dbRDA 1 & $\mathrm{R}$ & \\
\hline Ampelisca tenuicornis & $-0.41 \quad(-0.24)$ & Amphiura chiajei & 0.50 & $(0.30)$ \\
\hline Phoronis muelleri & $-0.38 \quad(-0.20)$ & Ophiocten affinis & 0.26 & $(0.05)$ \\
\hline Rhodine gracilior & $-0.37 \quad(-0.22)$ & Labidoplax buskii & 0.25 & $(0.18)$ \\
\hline Mysella bidentata & $-0.34 \quad(-0.21)$ & Lipobranchius jeffreysii & 0.22 & $(0.13)$ \\
\hline Nephtys hombergii & $-0.33 \quad(-0.19)$ & Philomedes brenda & 0.22 & $(0.02)$ \\
\hline Turritella communis & $-0.29 \quad(-0.17)$ & Abyssoninoe hibernica & 0.22 & $(0.25)$ \\
\hline Prionospio fallax & $-0.29 \quad(-0.25)$ & Nuculana pernula & 0.21 & $(0.05)$ \\
\hline Mysia undata & $-0.28 \quad(-0.16)$ & Brada villosa & 0.21 & $(0.09)$ \\
\hline Scoloplos armiger & $-0.28 \quad(-0.23)$ & Ophiodromus flexuosus & 0.21 & $(0.23)$ \\
\hline Praxillella praetermissa & $-0.27 \quad(-0.05)$ & Panthalis oerstedi & 0.19 & $(0.10)$ \\
\hline Pholoe baltica & $-0.26 \quad(-0.19)$ & Leucon nasica & 0.18 & $(0.00)$ \\
\hline Eudorella truncatula & $-0.25 \quad(-0.21)$ & Photis longicaudata & 0.16 & $(0.00)$ \\
\hline
\end{tabular}




\begin{tabular}{|c|c|c|c|c|c|}
\hline Aoridae & -0.25 & $(-0.17)$ & Hyala vitrea & 0.15 & $(0.07)$ \\
\hline Amphiura filiformis & -0.25 & $(-0.11)$ & & & \\
\hline Chamelea striatula & -0.24 & $(-0.17)$ & & & \\
\hline Trichobranchus roseus & -0.24 & $(-0.05)$ & & & \\
\hline Pectinaria auricoma & -0.23 & $(-0.10)$ & & & \\
\hline Nucula nitidosa & -0.21 & $(-0.14)$ & & & \\
\hline Scalibregma inflatum & -0.21 & $(-0.11)$ & & & \\
\hline Edwardsia spp. & -0.20 & $(-0.21)$ & & & \\
\hline Terebellides stroemi & -0.20 & $(0.09)$ & & & \\
\hline Sphaerodorum flavum & -0.19 & $(-0.11)$ & & & \\
\hline Ampelisca brevicornis & -0.19 & $(-0.16)$ & & & \\
\hline Dosinia lupines & -0.19 & $(-0.17)$ & & & \\
\hline Abra nitida & -0.19 & $(0.09)$ & & & \\
\hline Corbula gibba & -0.19 & $(0.00)$ & & & \\
\hline Harpinia antennaria & -0.19 & $(-0.16)$ & & & \\
\hline Notomastus latericeus & -0.17 & $(-0.11)$ & & & \\
\hline Levinsenia gracilis & -0.17 & $(-0.01)$ & & & \\
\hline Bela brachystoma & -0.17 & $(-0.14)$ & & & \\
\hline Anobothrus gracilis & -0.17 & $(-0.09)$ & & & \\
\hline Cylichna cylindracea & -0.17 & $(0.02)$ & & & \\
\hline Spiophanes bombyx & -0.16 & $(-0.15)$ & & & \\
\hline
\end{tabular}




\begin{tabular}{|lll|}
\hline Gari fervensis & -0.16 & $(-0.11)$ \\
\hline Magelona alleni & $-0.16 \quad(-0.15)$ \\
\hline Chone fauveli & $-0.15 \quad(-0.12)$ \\
\hline Spio filicornis & $-0.14 \quad(-0.16)$ \\
\hline Arctica islandica & $-0.14 \quad(-0.20)$ \\
\hline Virgularia mirabilis & $-0.14 \quad(-0.13)$ \\
\hline Westwoodilla caecula & -0.14 & $(-0.05)$ \\
\hline
\end{tabular}

884

885 
886 Table 2. Summary statistics of GAM of number of species (Nspp), total abundance (Nind),

887 biomass (Biom), Richness according to Margalef $(d)$, diversity according to Shannon $\left(H^{\prime}\right)$,

888 Benthic Quality Index (BQI), and for the dominating Amphiura species by abundance.

889 Equivalent degrees of freedom, is reported for the non-parametric predictors depth (D),

890 trawling intensity (TI) and total abundance (Nind) and statistical significance $(* \mathrm{P}<0.05$, **

$891 \mathrm{P}<0.01)$ for all terms. The family distribution adopted for each model and the $\mathrm{R}^{2}$ are

892 included.

893

\begin{tabular}{|c|c|c|c|c|c|c|}
\hline \multirow{2}{*}{ Response } & \multicolumn{4}{|c|}{ Predictor variable } & \multirow{2}{*}{$\mathrm{R}^{2}$} & \multirow{2}{*}{ Family } \\
\hline & a Year & $\mathrm{s}(\mathrm{D})$ & $\mathrm{s}(\mathrm{TI})$ & s(Nind) & & \\
\hline Nspp & $* *$ & 1.00 & $2.29 * *$ & $1.00 * *$ & 0.344 & Poisson \\
\hline Nind & & $1.93 * *$ & 1.00 & & 0.130 & Poisson \\
\hline $\ln ($ biomass $)$ & * & 1.00 & 1.00 & & 0.015 & Gaussian \\
\hline$\sqrt{d}$ & & 1.57 & $2.64 * *$ & & 0.177 & Gaussian \\
\hline$H^{\prime}$ & $* *$ & 1.00 & $2.36^{* *}$ & & 0.103 & Gaussian \\
\hline$B Q I$ & $* *$ & 1.76 & $2.54 * *$ & & 0.187 & Gaussian \\
\hline Amphiura chiajei & & $1.95 * *$ & $2.64 * *$ & & 0.283 & Poisson \\
\hline Amphiura filiformis & & $1.91 * *$ & 1.00 & & 0.132 & Poisson \\
\hline
\end{tabular}

894 


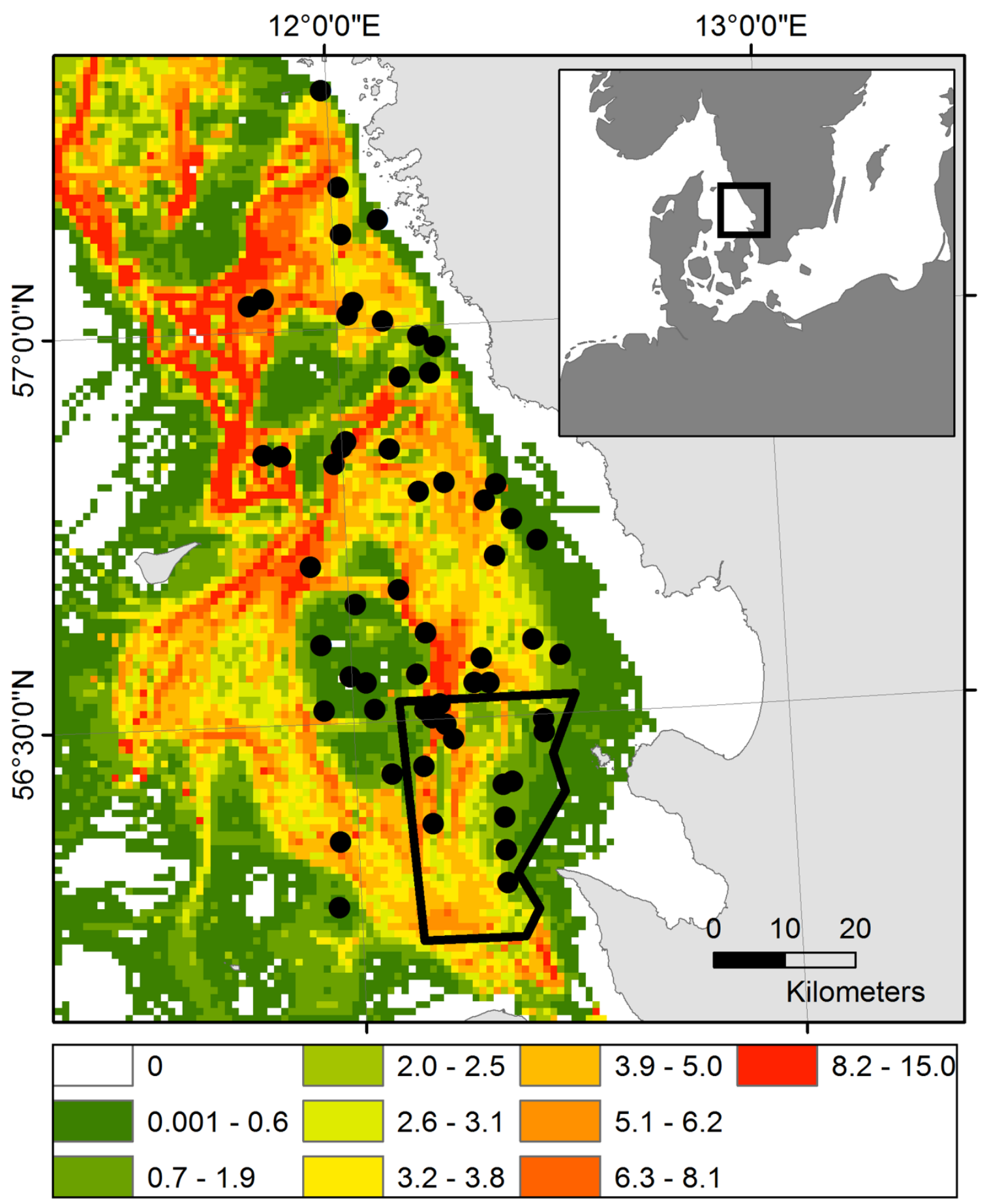

896 Fig. 1. Map of the study area in Kattegat. Colours indicate yearly averaged trawling intensity

897 averaged per year for 2006-2008, i.e. the period before the MPA was established in 2009.

898 Trawling intensity is estimated from Danish and Swedish VMS and logbook data of bottom

899 trawl fleets as the total area swept yearly in grid cells of $1 \times 1 \mathrm{~km}$ divided by grid cell size.

900 Sampling stations for benthic macrofauna are indicated with black dots and the MPA is

901 delineated. 


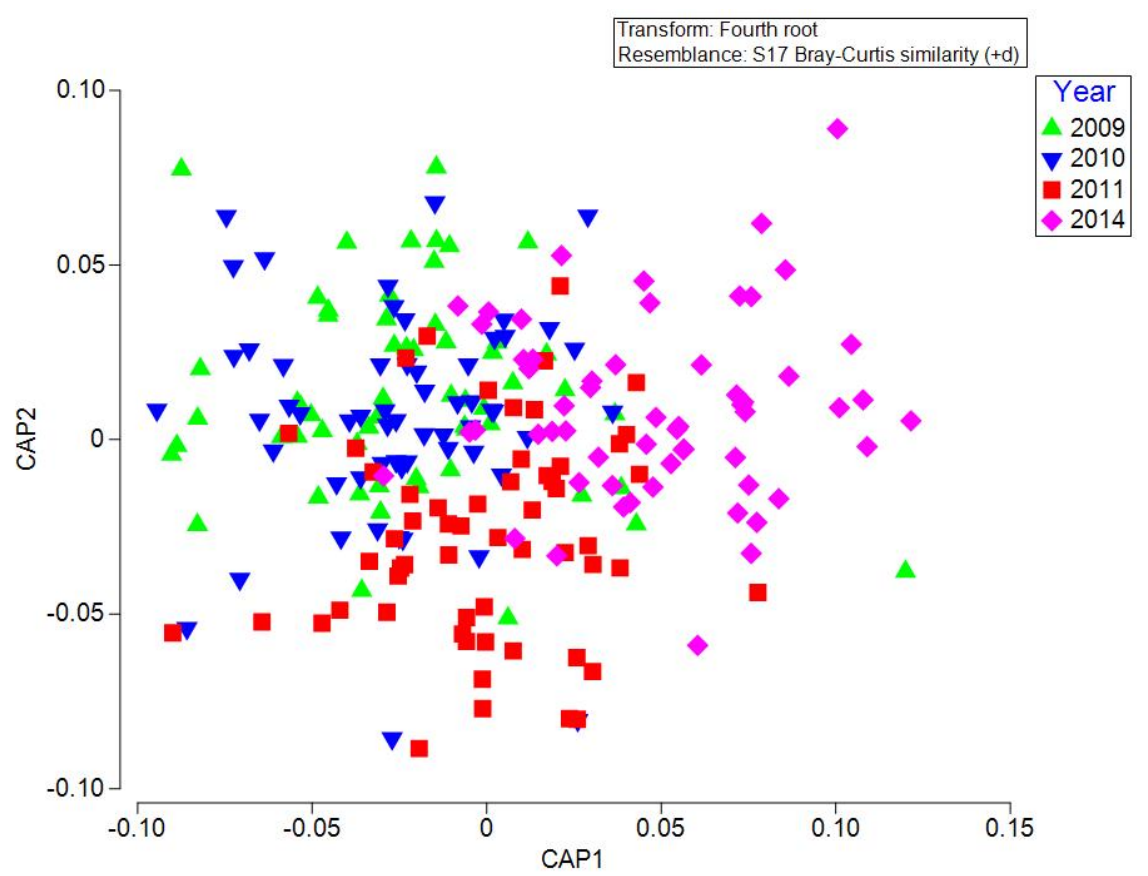

903

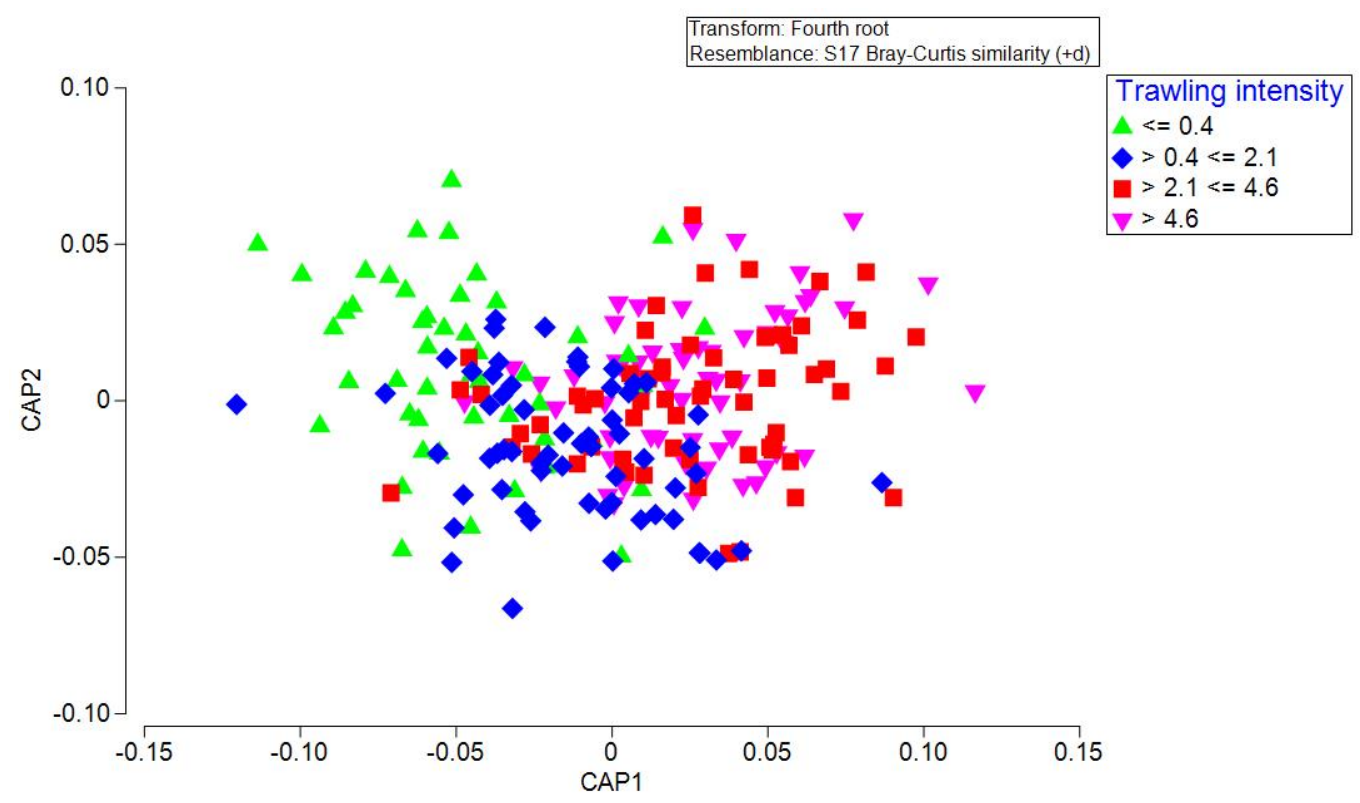

904 b.

905

906 Fig. 2. Canonical analysis of principal coordinates (CAP) for visual presentation of

907 macrofauna community composition (abundance of species) as shaped by (a) Year and (b)

908 Trawling intensity $\left(\mathrm{yr}^{-1}\right)$ grouped into statistical quartiles as indicated in the legend. 


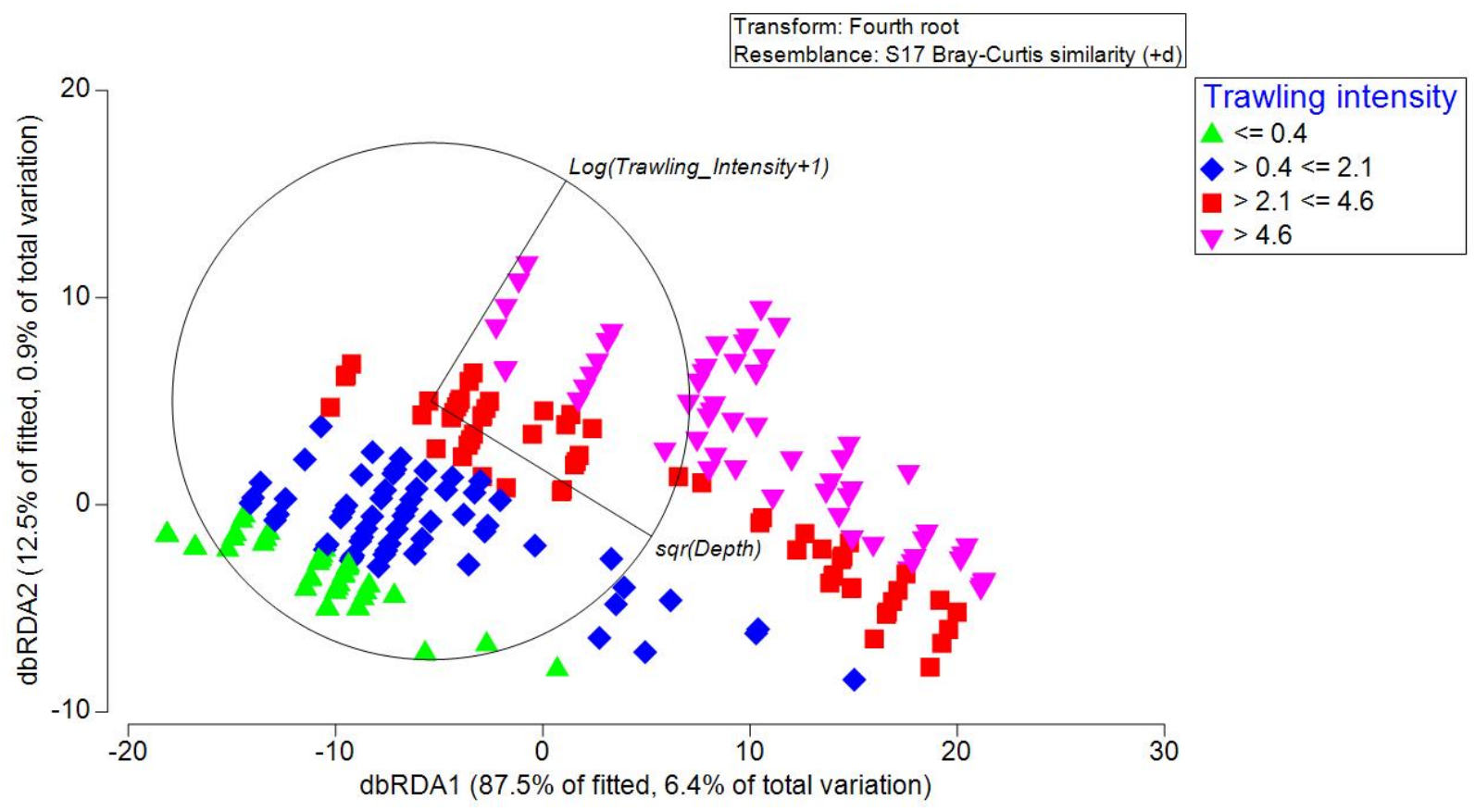

910

911 Fig. 3. Distance based redundancy analysis (dbRDA)ordination of the fitted model of the

912 macrofaunal community composition. The gradient in trawling intensity grouped into

913 quartiles is illustrated by the sampling stations colour according to the legend and vectors of

914 the predictors trawling intensity and depth are indicated in the plot.

915

916

917 

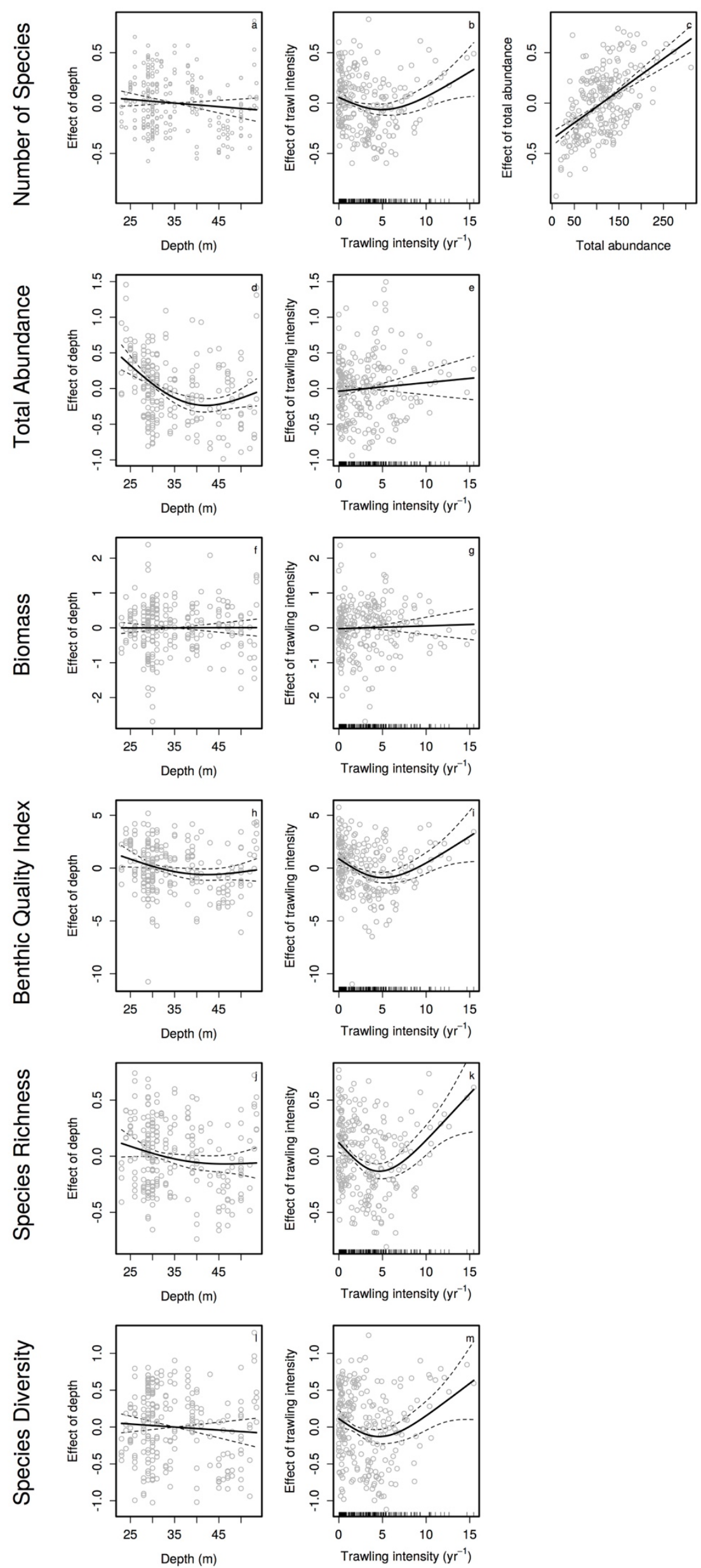
919 Fig. 4. Effect of different predictors on the number of species Nspp (a-c), total abundance

920 Nind (d-e), biomass (f-g), Benthic Quality Index (BQI, h-i) Richness according to Margalef $921(d, \mathrm{j}-\mathrm{k})$, diversity according to Shannon $\left(H^{\prime}, 1-\mathrm{m}\right)$ as estimated from GAMs with $95 \%$

922 confidence interval (dotted lines) and partial residuals (grey dots).

923 

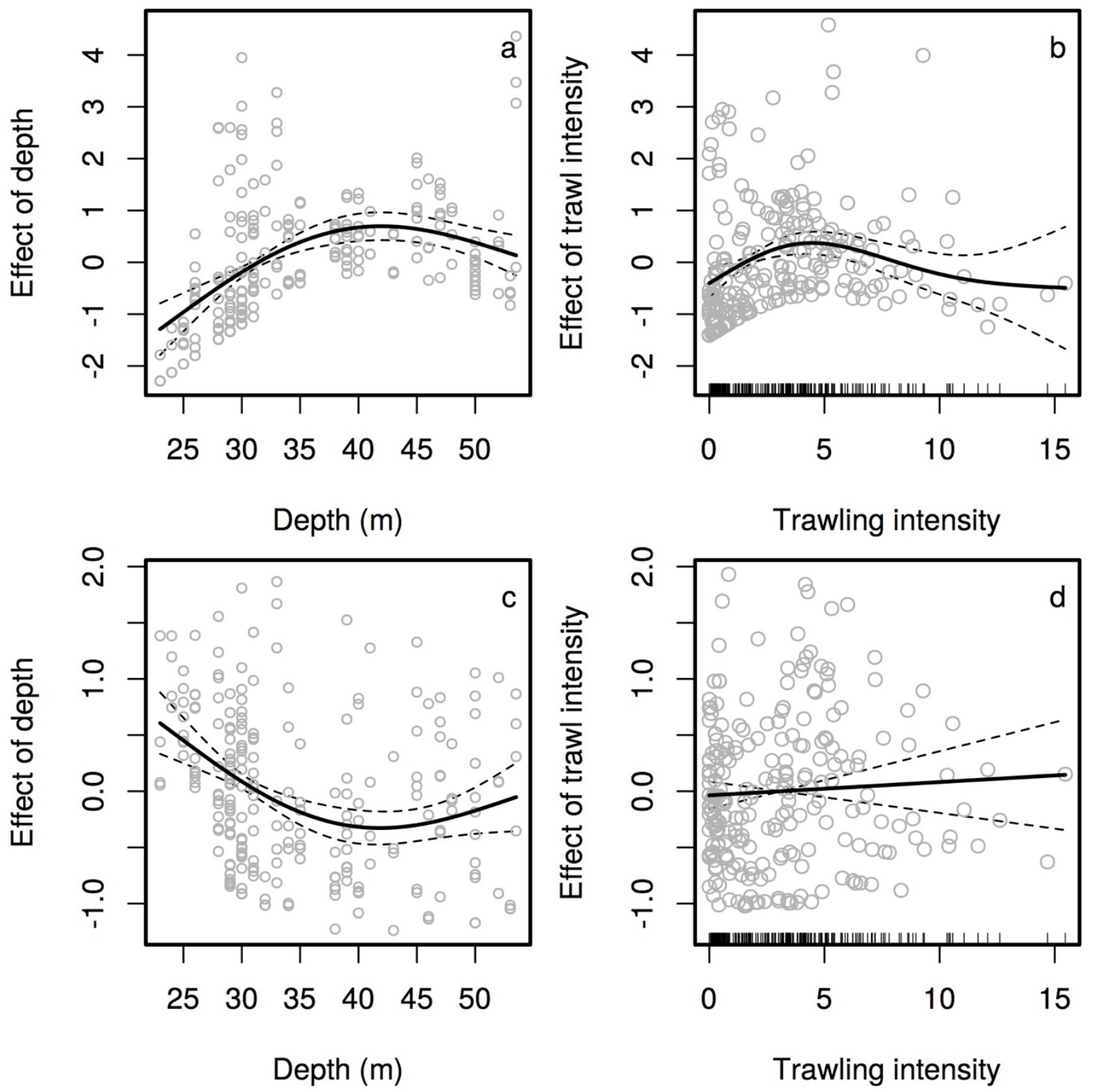

927 Fig. 5. Effect of different predictors on abundance of Amphiura chiajei (a-b) and Amphiura

928 filiformis (c-d) as estimated from GAMs with 95\% confidence interval (dotted lines) and 929 partial residuals (grey dots).

930 


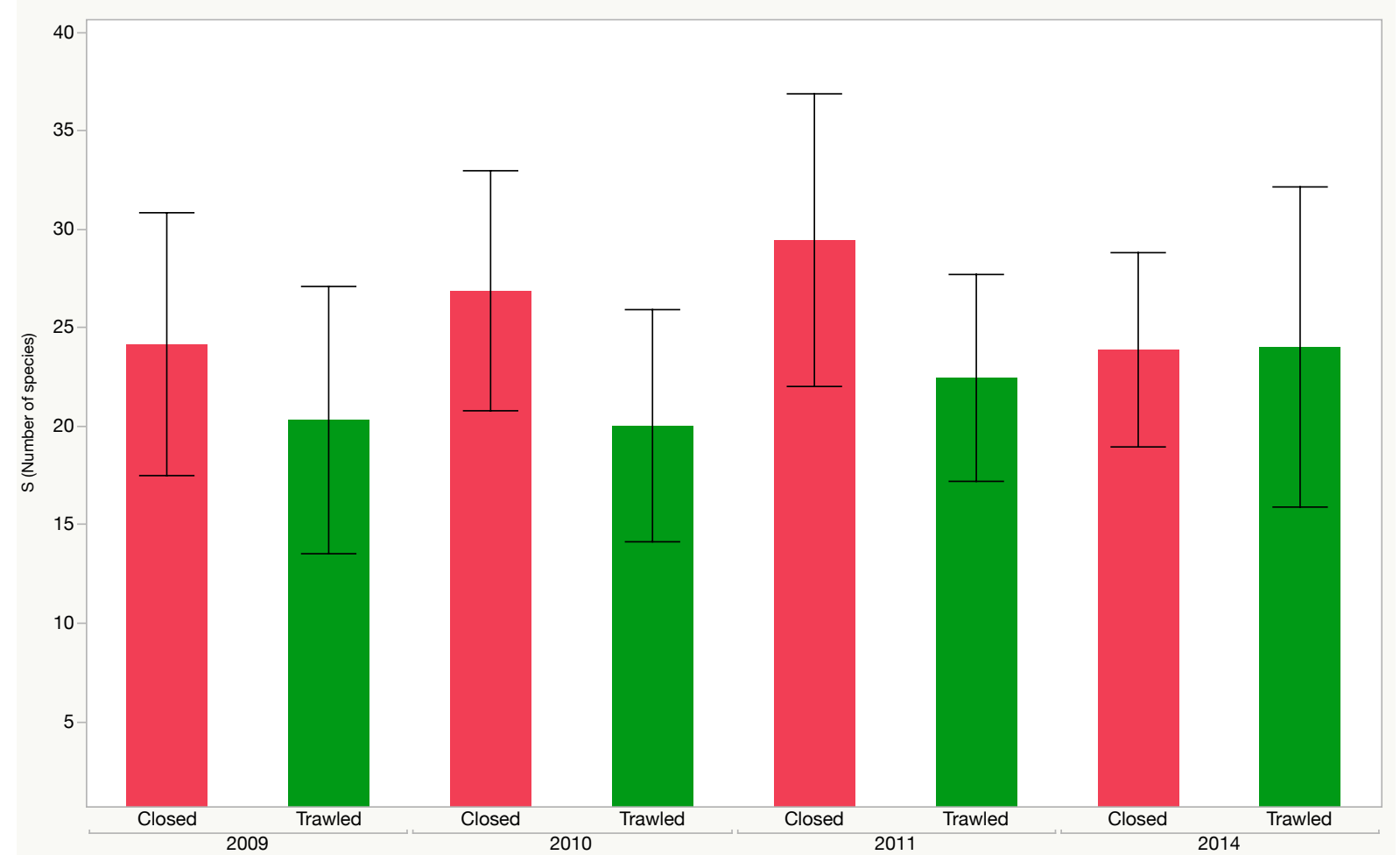

250

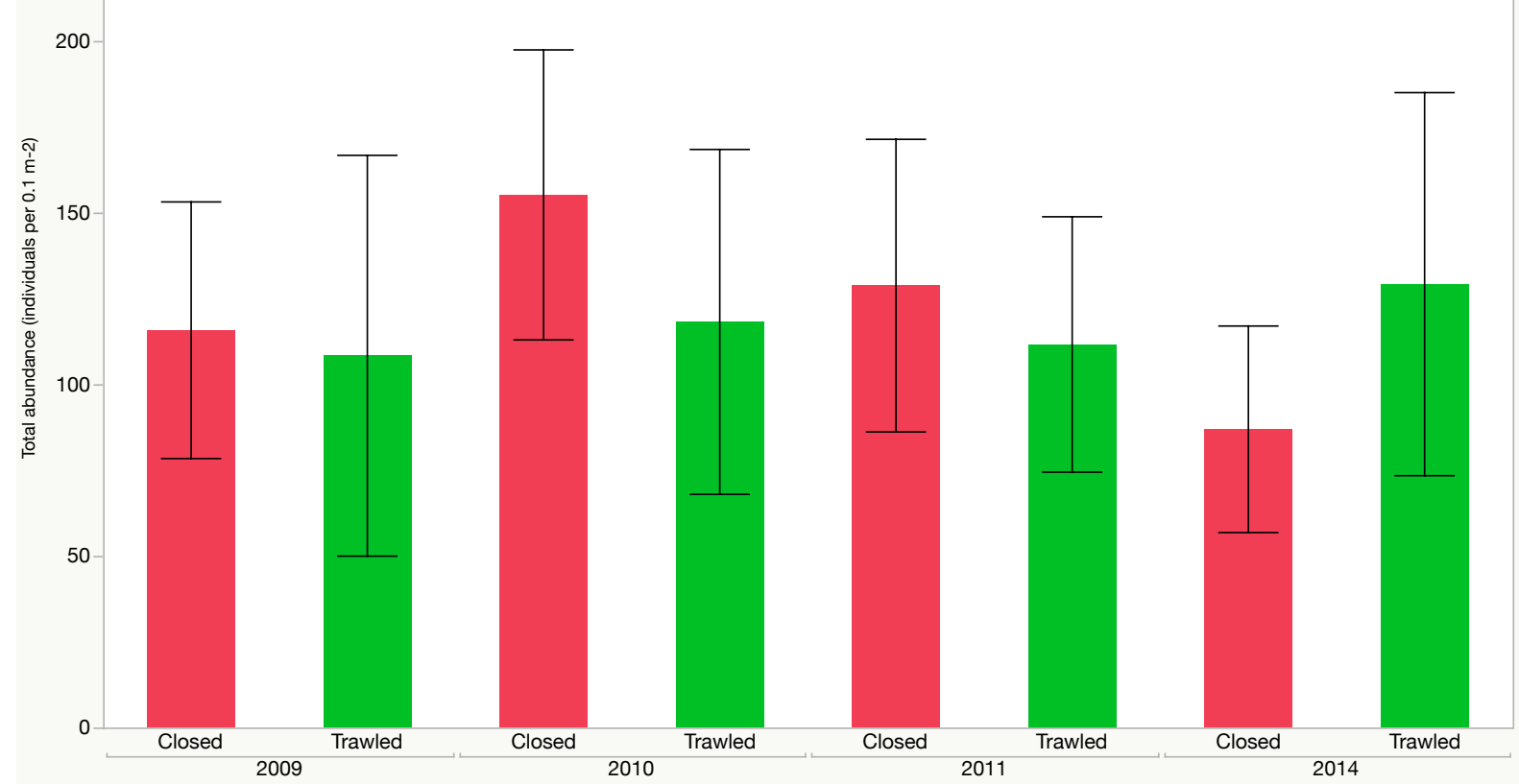




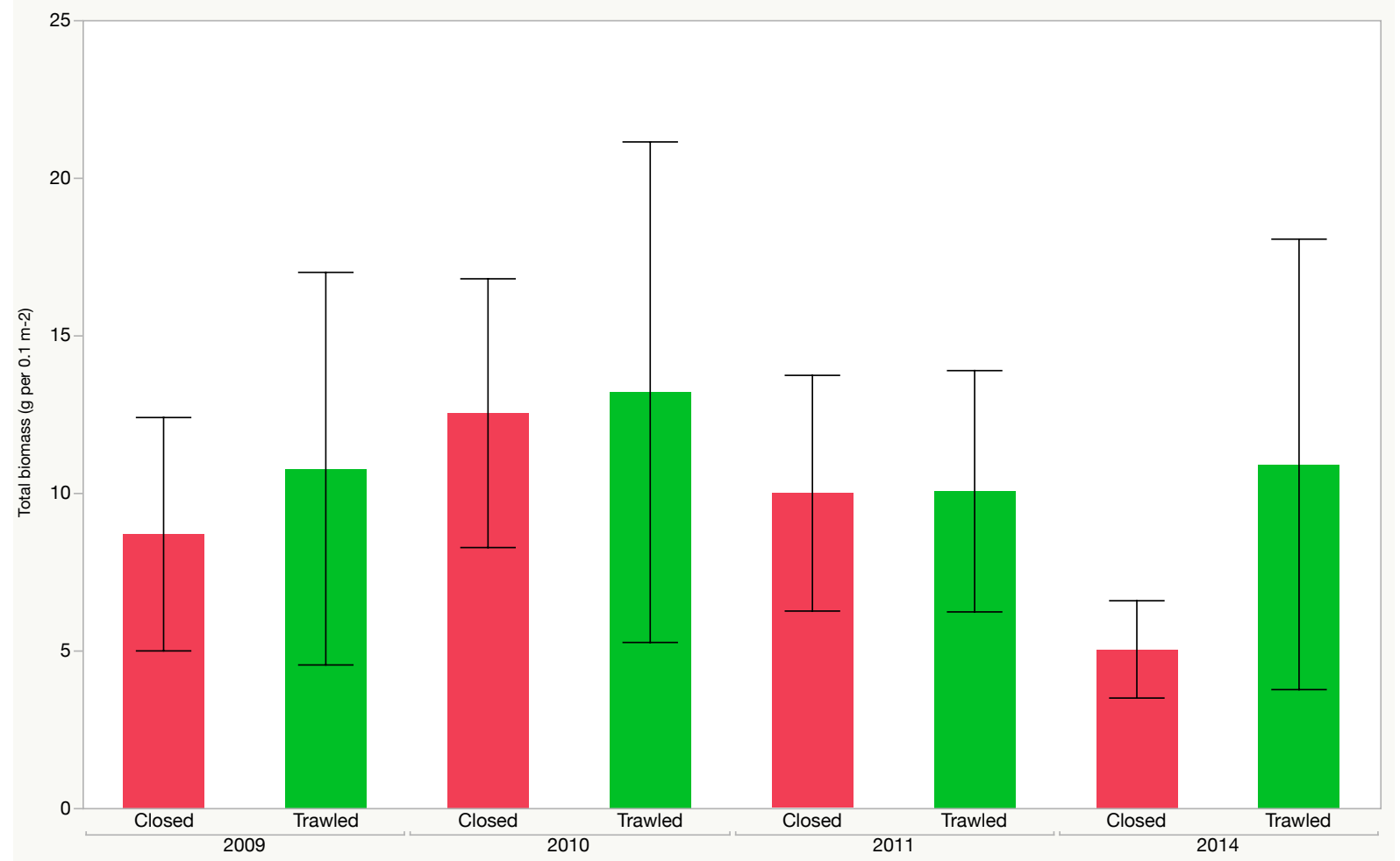

936

937 c)

938 Fig. 6. Macrofauna number of species (a), total abundance (b) and total biomass excluding

939 large bodied species (c) across years in the MPA (red, n=7) and continuously trawled area

940 (green, $\mathrm{n}=7$ ). Error bars are $95 \%$ confidence intervals.

941

942 


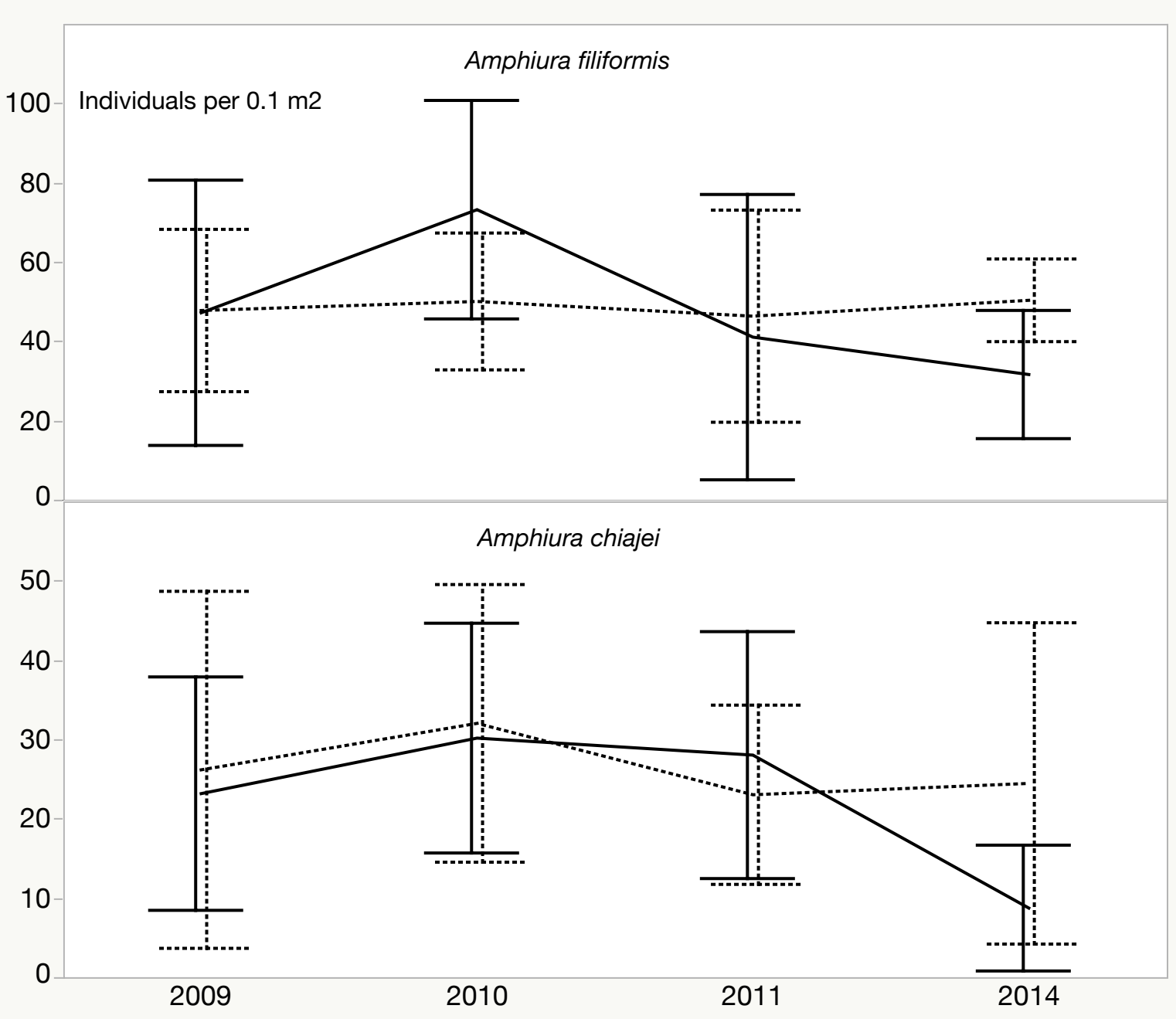

943

944 Fig. 7. Abundance of Amphiura filiformis (upper panel) and Amphiura chiajei (lower panel)

945 across years in the closed MPA (solid line, $\mathrm{n}=7$ ) and continuously trawled area (dotted line,

$946 \mathrm{n}=7)$. Error bars are standard deviation of the mean 